\title{
Late Saalian and Eemian palaeoenvironmental history of the Bol'shoy Lyakhovsky Island (Laptev Sea region, Arctic Siberia)
}

ANDREI A. ANDREEV, GUIDO GROSSE, LUTZ SCHIRRMEISTER, SVETLANA A. KUZMINA, ELENA YU. NOVENKO, ANATOLY A. BOBROV, PAVEL E. TARASOV, BORIS P. ILYASHUK, TATIANA V. KUZNETSOVA, MATTHIAS KRBETSCHEK, HANNO MEYER AND VIKTOR V. KUNITSKY

\section{BOREAS}

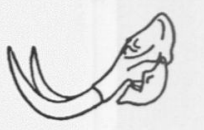

Andreev, A. A., Grosse, G., Schirrmeister, L., Kuzmina, S. A., Novenko, E. Yu., Bobrov, A. A., Tarasov, P. E., Ilyashuk, B. P., Kuznetsova, T. V., Krbetschek, M., Meyer, H. \& Kunitsky, V. V. 2004 (November): Late Saalian and Eemian palaeoenvironmental history of the Bol'shoy Lyakhovsky Island (Laptev Sea region, Arctic Siberia). Boreas, Vol. 33, pp. 319-348. Oslo. ISSN 0300-9483.

Palaeoenvironmental records from permafrost sequences complemented by infrared stimulated luminescence (IRSL) and ${ }^{230} \mathrm{Th} / \mathrm{U}$ dates from Bol'shoy Lyakhovsky Island $\left(73^{\circ} 20^{\prime} \mathrm{N}, 141^{\circ} 30^{\prime} \mathrm{E}\right)$ document the environmental history in the region for at least the past $200 \mathrm{ka}$. Pollen spectra and insect fauna indicate that relatively wet grasssedge tundra habitats dominated during an interstadial c. 200-170 ka BP. Summers were rather warm and wet, while stable isotopes reflect severe winter conditions. The pollen spectra reflect sparser grass-sedge vegetation during a Taz (Late Saalian) stage, $c .170-130 \mathrm{ka} \mathrm{BP}$, with environmental conditions much more severe compared with the previous interstadial. Open Poaceae and Artemisia plant associations dominated vegetation at the beginning of the Kazantsevo (Eemian) c. $130 \mathrm{ka}$ BP. Some shrubs (Alnus fruticosa, Salix, Betula nana) grew in more protected and wetter places as well. The climate was relatively warm during this time, resulting in the melting of Saalian ice wedges. Later, during the interglacial optimum, shrub tundra with Alnus fruticosa and Betula nana s.l. dominated vegetation. Climate was relatively wet and warm. Quantitative pollen-based climate reconstruction suggests that mean July temperatures were $4-5^{\circ} \mathrm{C}$ higher than the present during the optimum of the Eemian, while late Eemian records indicate significant climate deterioration.

Andrei A. Andreev (e-mail: aandreev@awi-potsdam.de), Guido Grosse, Lutz Schirrmeister, Hanno Meyer and Pavel E. Tarasov, Alfred Wegener Institute for Polar and Marine Research, Research Unit Potsdam, Telegrafenberg A43, D-14473 Potsdam, Germany; Svetlana A. Kuzmina, Paleontological Institute, RAS Profsoyuznaya 123, 117997 Moscow, Russia; Elena Yu. Novenko, Institute of Geography RAS, Staromonetny 29, 109017 Moscow, Russia; Anatoly A. Bobrov, Faculty of Soil Science Moscow State University, Vorobievy Gory, 119992 Moscow, Russia; Boris P. Ilyashuk, Institute of North Industrial Ecology Problems, Kola Science Center, Russian Acadamy of Sciences, Fersman St. 14, 184200 Apatity, Russia; Tatiana V. Kuznetsova, Faculty of Geology, Moscow State University, Vorobievy Gory, 119992 Moscow, Russia; Matthias Krbetschek, Saxon Academy of Science, Quaternary Geochronology Section, Bernhard-von-Cotta-Str. 4, 09596 Freiberg, Germany; Viktor V. Kunitsky, Permafrost Institute, Siberian Branch Russian Academy of Science Yakutsk, Russia; received 24th November 2003, accepted 7th July 2004.
Palaeoenvironmental, especially palynological, studies have already been conducted on permafrost sections in the Northern Yakutia (Rybakova 1962; Giterman 19761977; Lozhkin 1977; Sher et al. 1977; Kaplina 1979; Kaplina et al. 1978, 1980; Kaplina \& Giterman 1983; Tomirdiaro 1980; Barkova 1982, 1990; Rybakova \& Kolesnikov 1983; Rybakova \& Pirumova 1986; Alekseev 1989, 1997; Makeyev et al. 1989, 2003; Igarashi et al. 1995; Andreev et al. 2001, 2002a), but only a few of them are relatively well dated and at a high resolution, making the chronological correlation of the reconstructed environmental fluctuations difficult.

In 1998-2001 the permafrost sequences on the Bykovsky Peninsula (Mamontovy Khayata site) and north of the Chekanovsky Ridge (Buor-Khaya site) were studied within the scope of the research project 'Palaeoclimate signals in ice-rich permafrost' established by the German-Russian science cooperation 'Laptev Sea System'. These multidisciplinary studies have greatly improved the knowledge of the Late Quaternary environmental history of the region (e.g.
Andreev et al. 2002a; Meyer et al. 2002a; Schwamborn et al. 2002; Krbetschek et al. 2002; Schirrmeister et al. 2002a, in press; Kienast 2002; Kuzmina 2002; Bobrov et al. 2004). The Quaternary deposits of the southern coast of Bol'shoy Lyakhovsky Island were first noted by Bunge (1887) and Toll (1897). First detailed studies were carried out much later by Romanovskii (1958a-c), according to whom the deposits consist of lagoon and flood-plain sediments. In contrast, Japanese researchers propose that the Ice Complex deposits were formed in a large swampy marshland on the dried Pleistocene Laptev Sea shelf (Nagaoka 1994; Nagaoka et al. 1995), whereas Kunitsky (1998) considers them to be formations connected with perennial snow patches on cryoplanation terraces.

Discussions about the age of the studied deposits are also controversial. According to Romanovskii (1958a, b) their age varies from the Middle/Late Pleistocene (for the oldest deposits) to the Holocene, whereas Arkhangelov et al. (1996), based on TL dates $(980 \pm 250 \mathrm{ka}$ and $950 \pm 250 \mathrm{ka}$ ) and palaeomagnetic analyses, pro- 


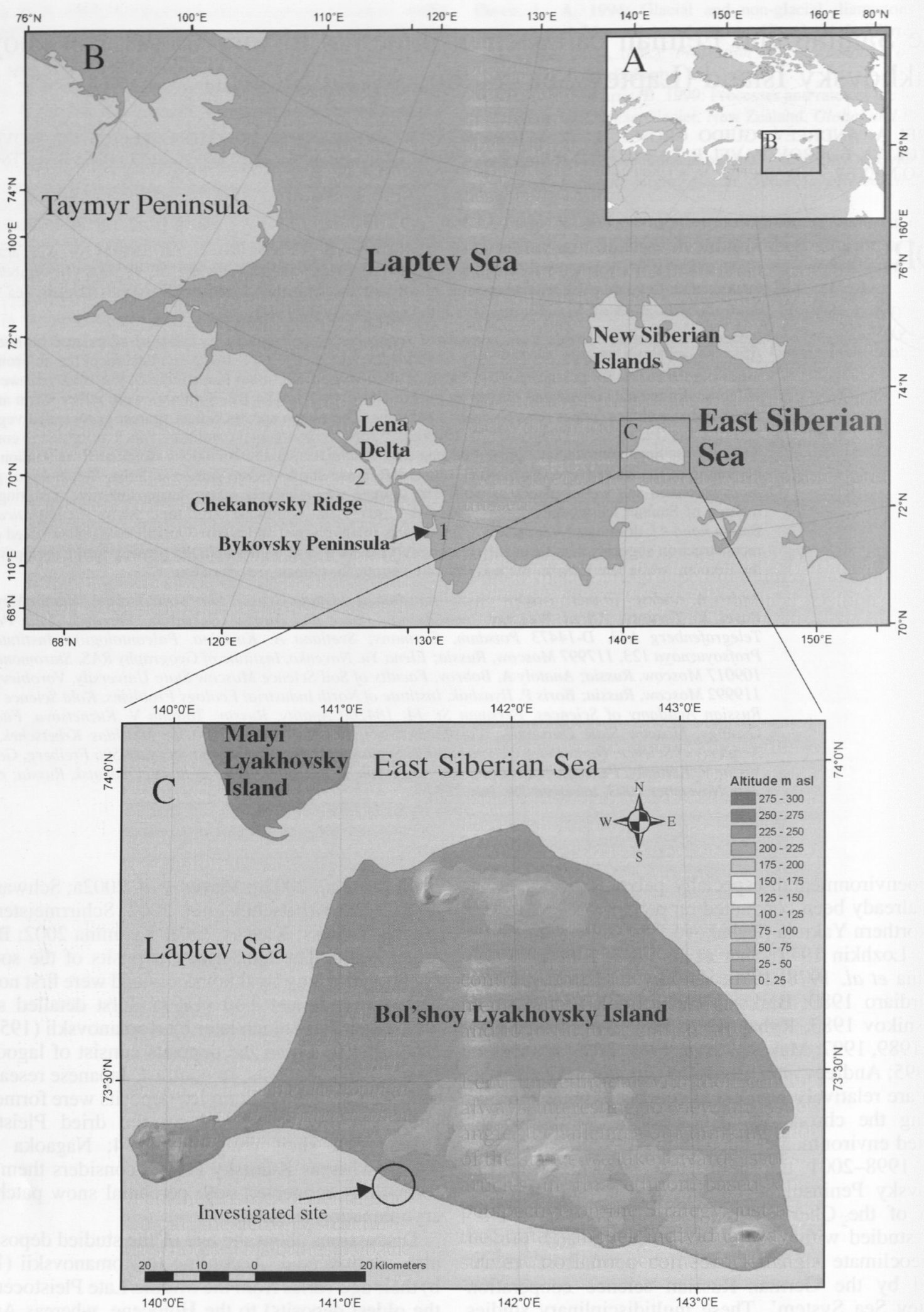

Fig. 1. A. Map of the Arctic. B. Map of the Laptev Sea - Bol'shoy Lyakhovsky Island region. 1 - Mamontovy Khayata site, 2 - Buor-Khaya site. C. Study area on Bol'shoy Lyakhovsky Island. 


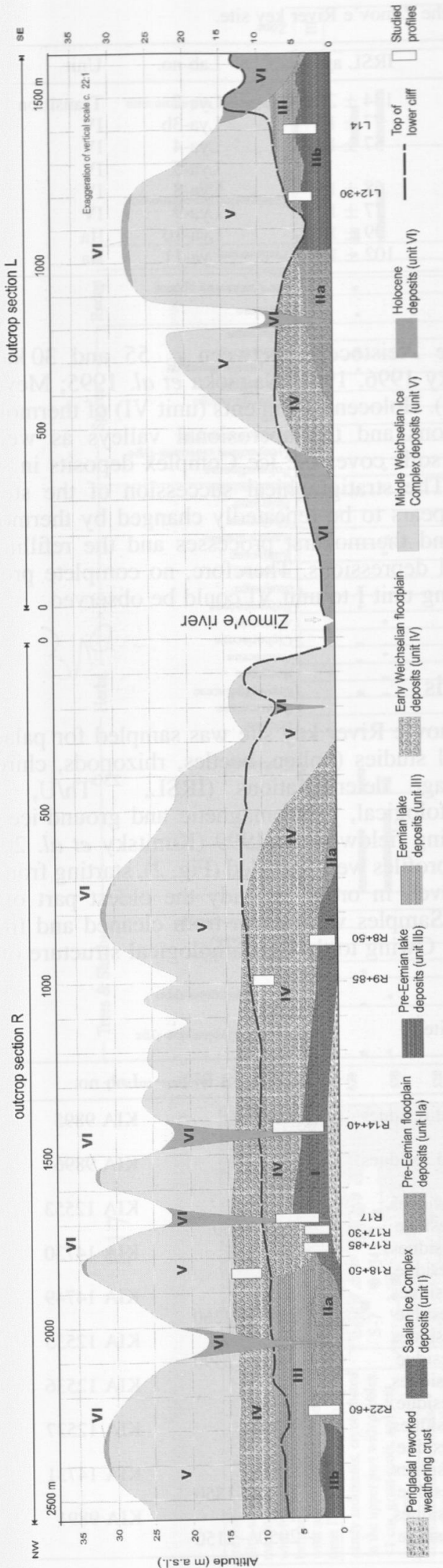

posed a late Pliocene/early Pleistocene age for the lowest deposits.

Recent studies of permafrost sequences from a key site situated on the southern coast of Bol'shoy Lyakhovsky Island at the mouth of Zimov'e River (Fig. 1) were also carried out within the scope of the project 'Palaeoclimate signals in ice-rich permafrost'. New palaeoenvironmental records dated by ${ }^{230} \mathrm{Th} / \mathrm{U}$, IRSL and ${ }^{14} \mathrm{C}$ methods document the environmental oscillations in the region from at least $c .200 \mathrm{ka}$ until the present. This paper presents new palaeoenvironmental reconstructions since an interstadial during the Taz (Late Saalian) time, prior to $200{ }^{230} \mathrm{Th} / \mathrm{U}$ ka ago up to the Zyryanian (Early Weichselian) stage $c$. 60-70 ka ago.

\section{Study area}

Large areas of the Bol'shoy Lyakhovsky Island are covered by ice-rich permafrost deposits. A key site located on the southern coast of Bol'shoy Lyakhovsky Island on the Dmitri Laptev Strait $\left(73^{\circ} 20^{\prime} \mathrm{N}, 141^{\circ} 30^{\prime} \mathrm{E}\right.$, Fig. 1) was studied in summer 1999. This site consists of coastal and thermoerosion cliffs up to $40 \mathrm{~m}$ high extending for about $2.5 \mathrm{~km}$ to the east and about $3.5 \mathrm{~km}$ to the west from the Zimov'e River mouth (Fig. 2).

The modern climate of the area is characterized by long ( 8 months), severe winters with January temperatures of -31 to $-32^{\circ} \mathrm{C}$ and short, cold summers with July temperatures around $4^{\circ} \mathrm{C}$ and about $200 \mathrm{~mm}$ annual precipitation (Atlas Arktiki 1985). Soils in the area are mainly tundra-gley and peaty-gley (histosols and inceptisols) with an active-layer thickness of about $30-40 \mathrm{~cm}$ (Atlas Arktiki 1985). Permafrost has a thickness of $500-600 \mathrm{~m}$ (Grigoriev et al. 1996). The area belongs to the northern tundra zone ( Atlas Arktiki 1985). Moss-grass-low-shrub tundra dominates the vegetation, with vascular plant species such as Salix pulchra, Cassiope tetragona, Dryas punctata, Oxyria digyna, Alopecurus alpinus, Poa arctica, Carex ensifolia, C. rotundifolia and Eriophorum medium, mosses such as Aulacomnium turgidum, Hylocomium alaskanum, Drepanocladus iniciatus and Calliergon sarmentosum and lichens such as Alectoria ochroleuca, Cetraria cuculliata and C. hiascus.

The lowest (oldest) frozen soft rocks are periglacially reworked remains of a yellowish to greenish coloured Palaeogene weathering crust exposed at sea level (Kunitsky et al. 2000). The overlaying unit (unit I) contains ice-rich silty and silty-sandy deposits with pebbles, peat inclusions and peat horizons. Ice belts, lens-like reticulated interlayers and wide ice wedges with symmetric shoulders are indicative of syngenetic permafrost conditions. Unit I is suggested to be the deposit of an old Ice Complex, similar to the Late Pleistocene (Weichselian) Ice Complex formation that 
Table 1. Infrared stimulated luminescence (IRSL) dates from the lower units of the Zimov'e River key site.

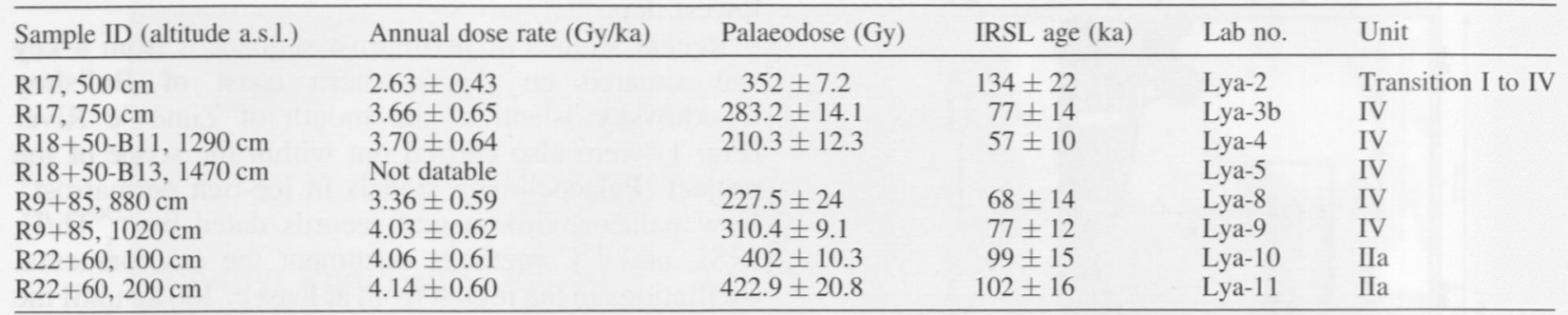

is widely distributed in northeastern Siberia. The next unit (unit II) mostly forms the lower part of the coastal cliff up to about $6 \mathrm{~m}$ a.s.l. Two different facies subunits were observed. Unit IIa consists of well-sorted, homogenous loess-like fine-grained silty to sandy, relatively ice-poor sediments with massive cryostructure containing numerous vertically orientated roots, small ice and sand-ice wedges. Unit IIb consists of laminated, bluishgrey sediments containing numerous shells of the freshwater molluscs (Pisidium sp., Sphaerium corneum, Valvata piscinalis, Lymnaea cf. peregra) and freshwater ostracods. Unit IIb is sinuously deformed (amplitude 2$3 \mathrm{~m}$, length $10-20 \mathrm{~m}$ ) and sporadically covered by a horizon of ice-wedge casts with laminated subaquatic deposits (unit III). Younger loess-like deposits, very similar to unit IIa, exposed between 3 and $15 \mathrm{~m}$ a.s.l., are considered as unit IV. They contain more ice as ice belts and larger ice wedges. The subsequent Ice Complex deposits (unit V) form steep walls up to $25 \mathrm{~m}$ high. This unit is composed of wide (up to $6 \mathrm{~m}$ ) and long (up to $25 \mathrm{~m}$ ) ice wedges and sandy sediments with numerous peat lenses and palaeosol horizons, especially in the upper part. Unit V was formed during the Late Pleistocene, between $c .55$ and $30 \mathrm{ka} \mathrm{BP}$ (Kunitsky 1996, 1998; Nagaoka et al. 1995; Meyer et al. 2002). Holocene sediments (unit VI) of thermokarst depressions and thermoerosional valleys as well as modern soils cover the Ice Complex deposits in some places. The stratigraphical succession of the studied units appears to be repeatedly changed by thermoerosional and thermokarst processes and the refilling of temporal depressions. Therefore, no complete profiles containing unit I to unit VI could be observed.

\section{Methods}

The Zimov'e River key site was sampled for palaeoecological studies (pollen, beetles, rhizopods, chironomids), age determinations (IRSL, ${ }^{230} \mathrm{Th} / \mathrm{U},{ }^{14} \mathrm{C}$ ), sedimentological, palaeomagnetic and ground-ice studies during fieldwork in 1999 (Kunitsky et al. 2000). Several profiles were sampled (Fig. 2), starting from the beach level, in order to study the oldest part of the section. Samples were taken from cleaned and frozen deposits. Owing to the cryolithological structure of the

Table 2. AMS radiocarbon dates from the lower units of the Zimov'e River key site.

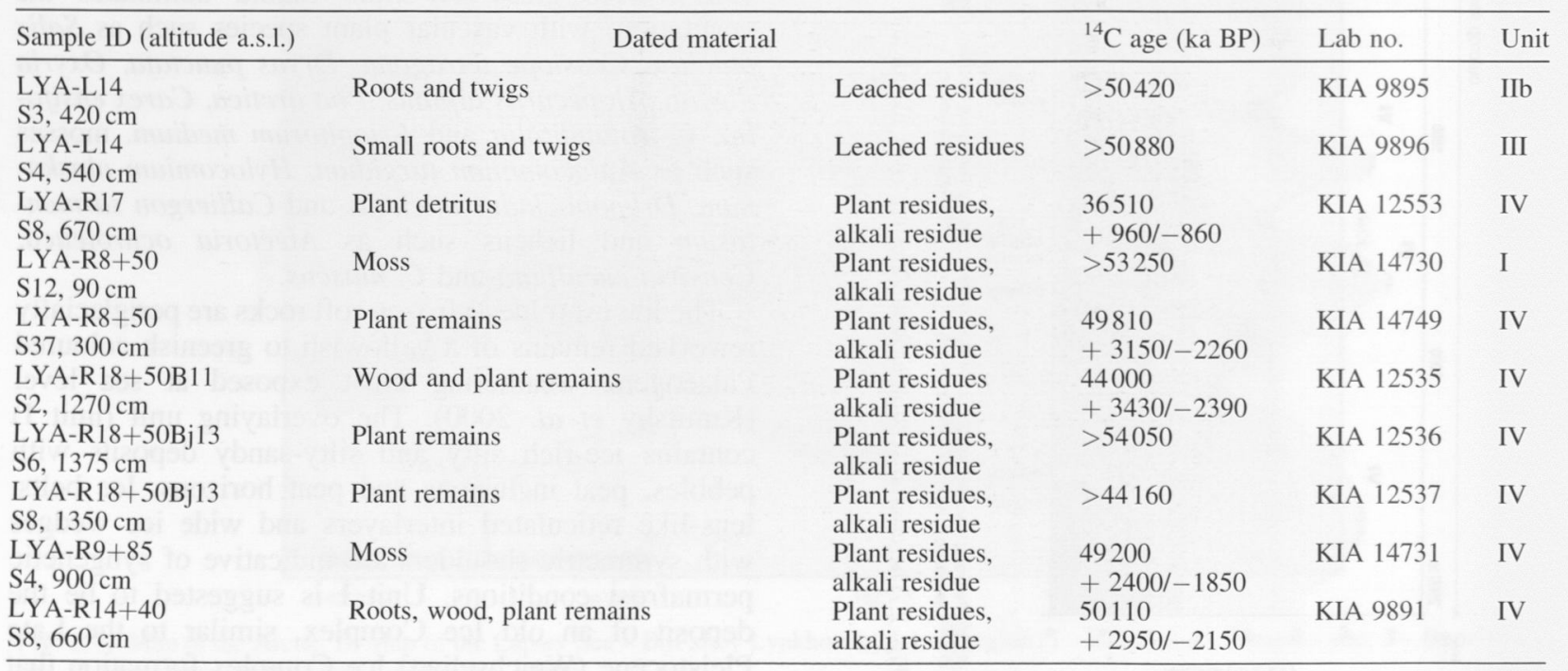




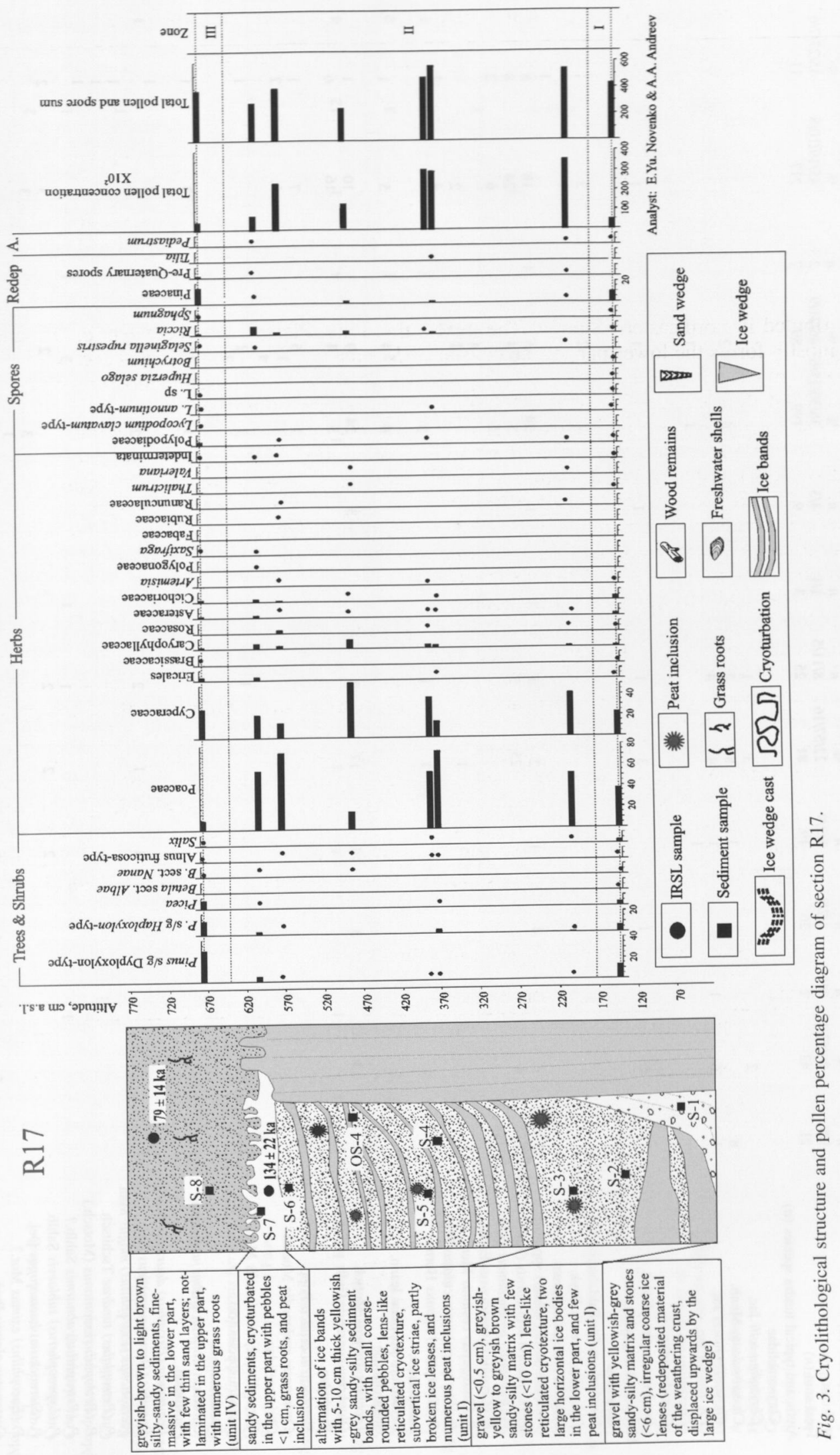




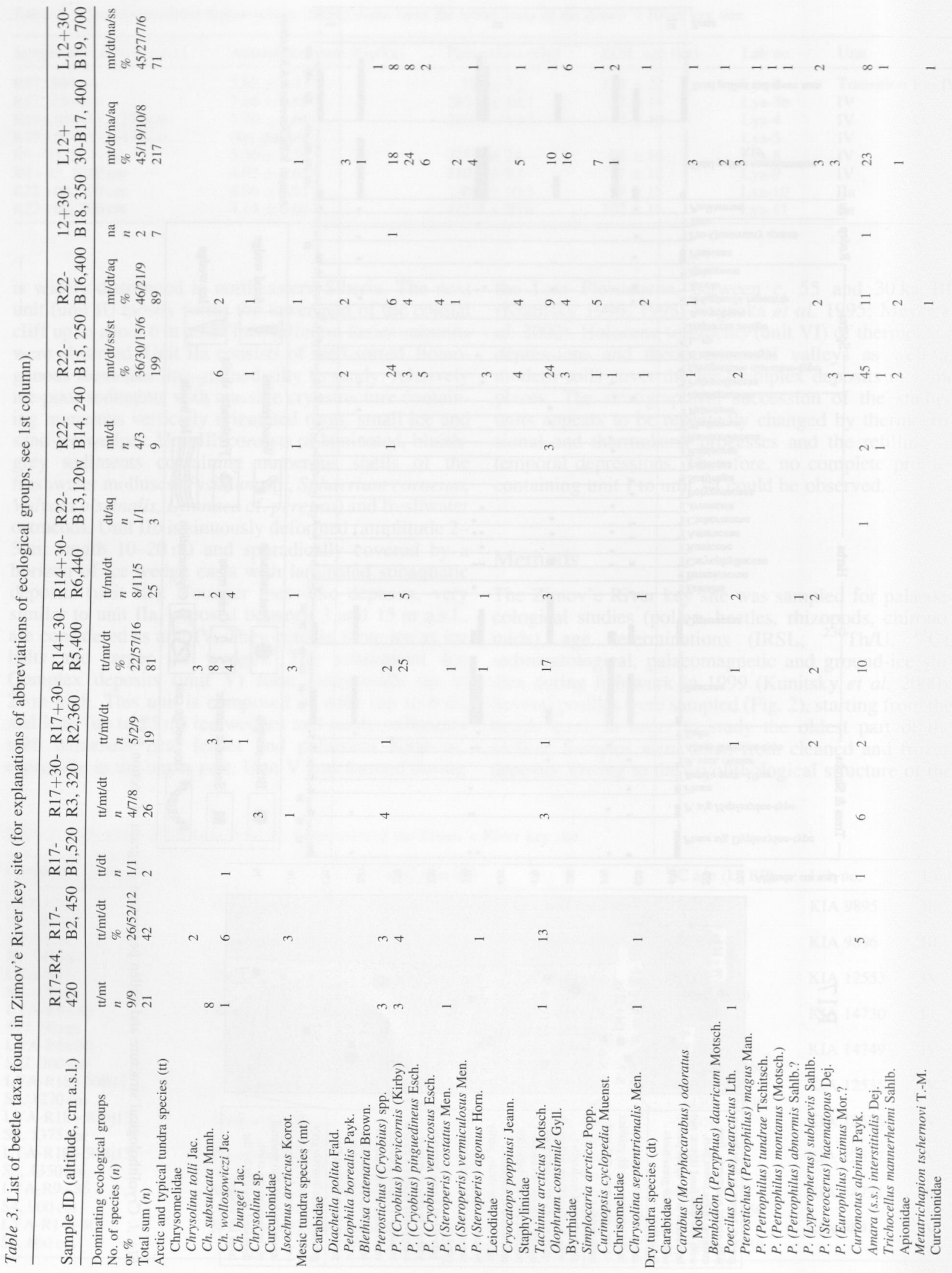


$\sqrt{2}$

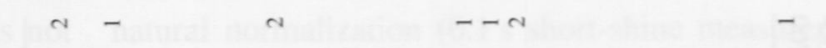

$-m$

44

I

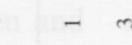

4

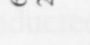

$-$

$--\quad$

$4-4$

a $m$ o

N

N 


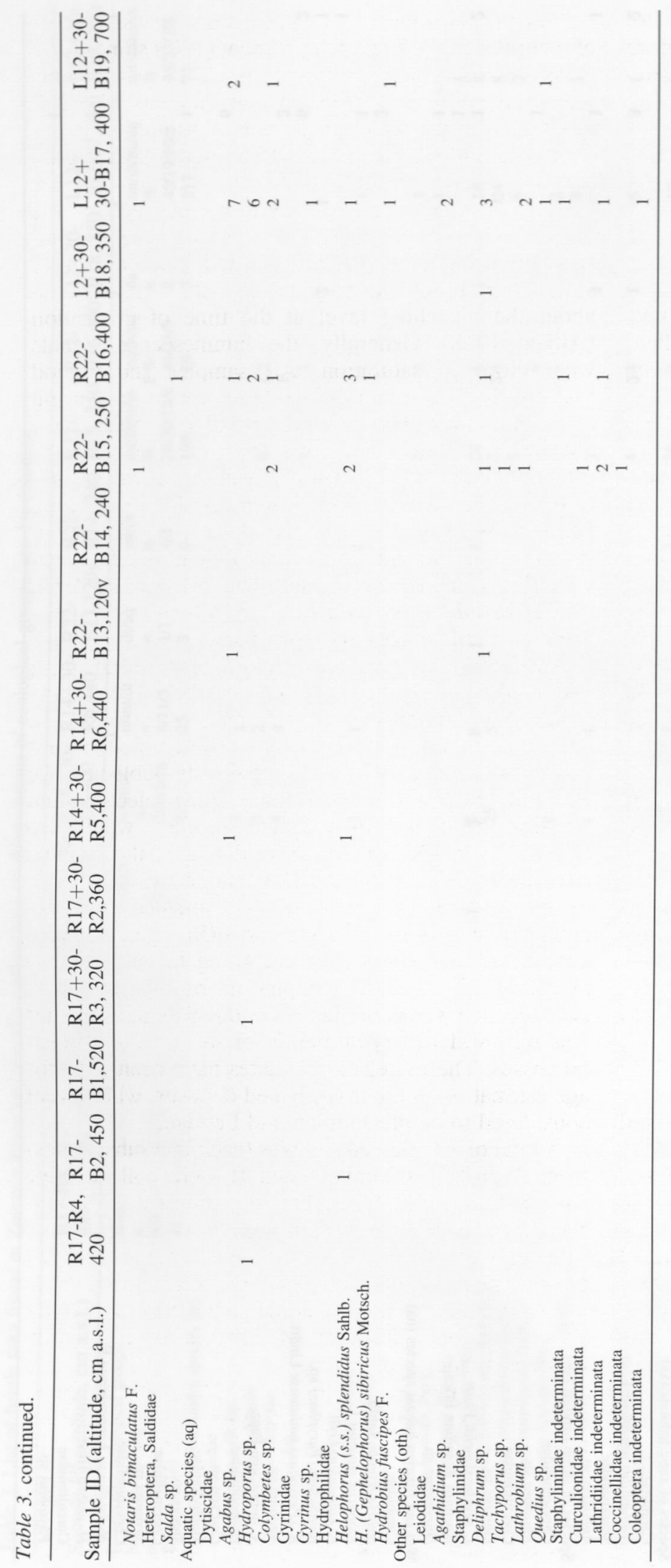


deposits and the geomorphologic situation, it was not possible to sample one continuous section; therefore samples were taken from thermokarst mounds (baydzharakhs) in which deposits remain in situ after melting of the surrounding ice wedges.

A standard $\mathrm{HF}$ technique was used for pollen preparation (Berglund \& Ralska-Jasiewiczowa 1986). At least $200^{*}$ pollen grains were counted in every sample. The relative frequencies of pollen taxa were calculated from the sum of the terrestrial pollen taxa. Spore percentages are based on the sum of pollen and spores. The relative abundances of reworked taxa (Tertiary spores and redeposited Quaternary pollen) are based on the sum of pollen and redeposited taxa, and the percentages of algae are based on the sum of pollen and algae. The Tilia/TiliaGraph software (Grimm 1991) was used for the calculation of percentages and for drawing the diagrams. Diagrams were zoned by visual inspection.

Samples for beetle remains were sieved through a $0.5 \mathrm{~mm}$ (samples marked with B) and $1 \mathrm{~mm}$ (samples marked with R) mesh. Originally, the R-marked samples were intended to be used for rodent analyses, but only a few rodent remains were found. The sample size varied from $40 \mathrm{~kg}$ (for detritus-rich samples) to $200 \mathrm{~kg}$ (for samples containing few plant and insect remains). Later, the insect remains were picked manually under a binocular microscope.

Samples for chironomid analysis were mixed with water, but were not sieved through a mesh. The analysis followed methods outlined in Walker (2001). Taxonomic identification was carried out followed Wiederholm (1983) and Makarchenko \& Makarchenko (1999).

Samples for testate amoebae analysis were sieved through a $0.5 \mathrm{~mm}$ mesh and testate amoebae shells were concentrated with a centrifuge. A drop of suspension was placed on the slide, and then glycerol was added. Normally, five subsamples were examined at $\times 200-400$ magnification with a light microscope.

Eight samples from selected profiles were dated by the infrared stimulated luminescence (IRSL) technique (Table 1). IRSL has already been successfully applied for dating Late Quaternary deposits in the Lena Delta (Krbetschek et al. 2002; Schirrmeister et al. in press). The additive dose protocol was used for calculation of the palaeodose (Aitken 1998). The samples, each divided into 48 aliquots, were stepwise radiated artificially with a $\mathrm{Sr} / \mathrm{Y} \beta$-irradiator. After irradiation the samples were heated at $140^{\circ} \mathrm{C}$ for $48 \mathrm{~h}$ to remove the unstable components of the luminescence signal. The IRSL measurements were carried out using a Risø TL/ OSL DA12 automated luminescence reader (Ris $\emptyset$ National Laboratory, Denmark). Luminescence stimulation was performed at a wavelength of $880 \mathrm{~nm}$ with an optical power of $40 \mathrm{~mW} \mathrm{~cm}^{-2}$. The IRSL of the $410 \mathrm{~nm}$ feldspar emission-peak (Krbetschek et al. 1997) was measured using a 410/10 nm FWHD interference bandpass optical filter (Andover Corp.). For each sample, natural normalization $(0.1 \mathrm{~s}$ short-shine measurements of natural signal), final measurement (100 s shine-down measurements) and fading tests $(0.1 \mathrm{~s}$ short-shine measurements repeated on the same aliquots after 2-3 months' storage) were conducted. A saturation exponential luminescence versus additive-dose characteristics was fitted using the ANALYST software (Duller 2001). The measurements were normalized by the natural short shine signal and a late-light subtraction was applied. The plateau-test (palaeodose versus stimulation time) was applied to obtain information about the bleaching level at the time of deposition (Aitken 1998). Generally, the luminescence signals were close to saturation. All samples show good plateaus with constant palaeodoses versus increasing stimulation time. The growth-curve fit was repeated for the final palaeodose and error determination using the integral values of the plateau. The dose-rate determination was performed by low-level high-resolution gamma spectrometry. For the dose-rate calculation, the natural radionuclides, cosmic radiation values and water/ice contents were used. The software of Grün (1992) based on procedures from Aitken (1985) was used to calculate ages and error bars.

Another dating technique used for peaty sediments at this study site is the ${ }^{230} \mathrm{Th} / \mathrm{U}$ method. The results obtained were published by Schirrmeister et al. (2002b).

As the general stratigraphy of the subsampled profiles was not clear in the field and previously published age determinations were controversial, some selected plant remains from the investigated profiles were also collected for AMS radiocarbon dating at the Leibniz Laboratory, Kiel (Table 2). The obtained ages are close to or beyond the limit of ${ }^{14} \mathrm{C}$ method and not comparable with the ${ }^{230} \mathrm{Th} / \mathrm{U}$ and IRSL ages, nor with geologically expected ages according to the stratigraphical positions of the samples in the outcrops. It is possible that some of the AMS-dated organic matter was removed by cryoturbation or by thermoerosional processes. Therefore, no ${ }^{14} \mathrm{C}$ dates have been used for age estimation of the investigated deposits, which were considered to be pre-Eemian and Eemian.

A total of 10 oriented samples (each in 6 subsamples) from 3 profiles of units I and II were collected for palaeomagnetic analyses. For the sampling, a 45-mm sheet-steel cube with flat surfaces has been used. The samples were stored in special $24 \times 24 \mathrm{~mm}$ cardboard boxes. The palaeomagnetic analyses were carried out at the Laboratory of Main Geomagnetic Field and Magnetic Petrology, Institute of Physics of the Earth, Russian Academy of Sciences.

The best modern analogue (BMA) method (Guiot 1990) was used to reconstruct climate characteristics from the pollen spectra attributed to the Eemian. The method has recently been applied to lateglacial and Holocene pollen records from the Russian Arctic (Andreev et al. 2003a, b, 2004). The accuracy of the BMA method in comparison with other pollen-based 


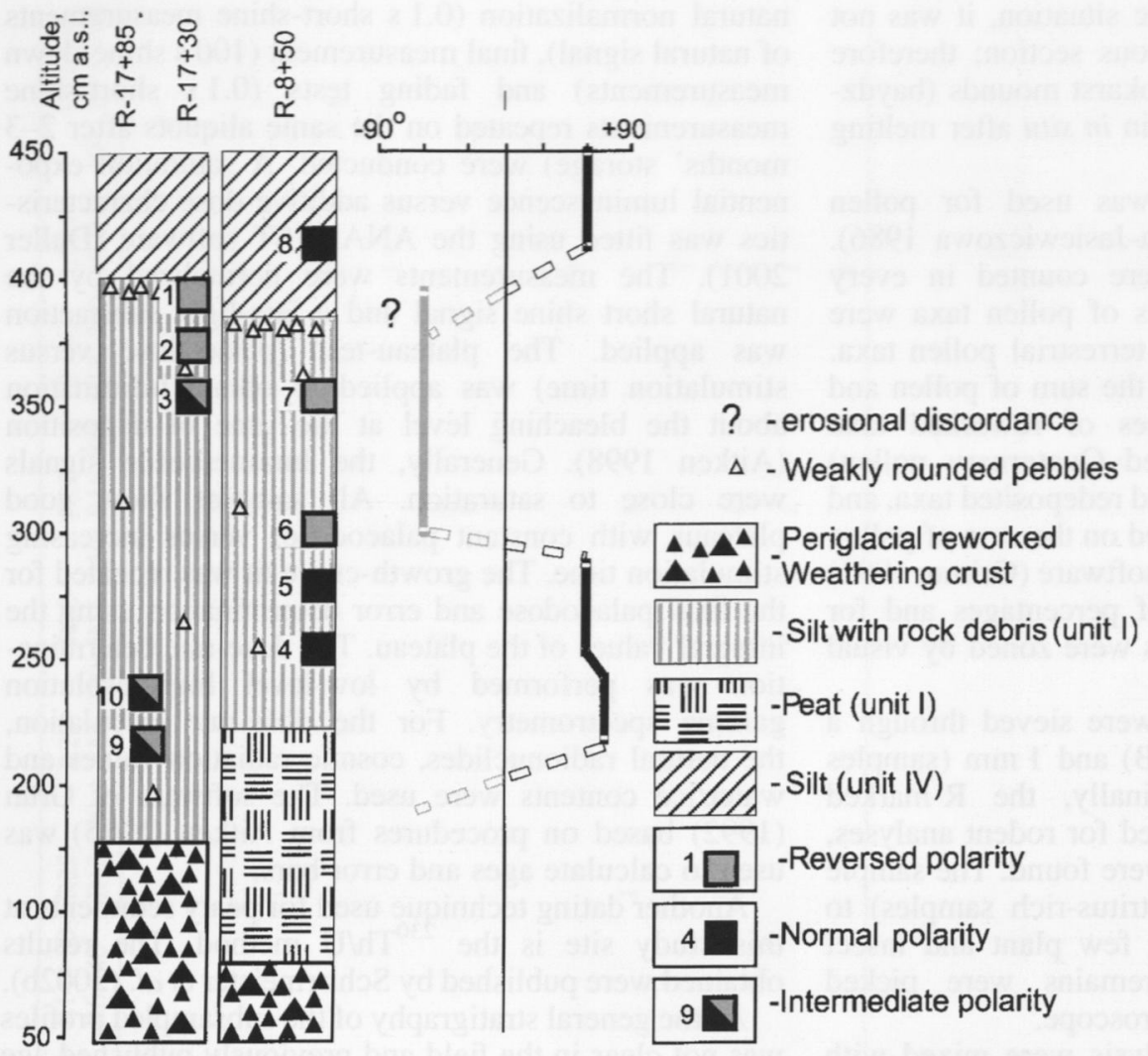

Fig. 4. Palaeomagnetic characteristics of sections $\mathrm{R} 17+30, \mathrm{R} 17+85$ and $\mathrm{R} 8+50$. reconstruction approaches is discussed in Andreev et al. (2003b). In the present study, the same reference data sets and calculation techniques as described in Andreev et al. (2003a, b, 2004) were used. Mean July temperature and the annual sum of mean-day temperatures above $5^{\circ} \mathrm{C}$ (GDD5) have the most definitive effect on Arctic vegetation (Kaplan 2001) and are reconstructed from surface pollen spectra from the Russian Arctic with the highest confidence (Andreev et al. 2003a, b).

\section{Results}

\section{Section R17}

The 570-cm R17 section largely consists of old Ice Complex silty to sandy deposits with some smaller pebbles and peat inclusions covered by loess-like silty deposits (Fig. 3). The sample from the periglacially reworked Palaeogene weathering crust $(80 \mathrm{~cm}$ a.s.l.) contains no pollen. Pollen spectra from deposits above can be divided into three pollen zones (Fig. 3). PZ-I consists of one sample from $160 \mathrm{~cm}$ a.s.l. and is notable for its low pollen concentration (5000 grains per $\mathrm{cm}^{3}$ ) and large amounts of reworked Pinaceae. The spectrum is dominated by Poaceae and Cyperaceae with some other herb pollen (Caryophyllaceae, Cichoriaceae,
Artemisia). PZ-II (c. 170-640 cm a.s.1.) is characterized by significantly higher pollen concentration (up to 35000 grains per $\mathrm{cm}^{3}$ ) and very low presence of reworked Pinaceae pollen. PZ-III (c. $640-670 \mathrm{~cm}$ a.s.1.) is similar to PZ-I.

The sample R17-R4 (420 cm a.s.1.) from a nearbysituated (less than $5 \mathrm{~m}$ ) subsection contains few beetle remains, mostly mesic tundra species and species from typical and arctic tundra habitats (Table 3 ). There is only one typical tundra-steppe species, Morychus viridis, a habitant of the so-called sedge heaths (xerophilous Carex argunensis and Polytrichum piliferum dominated associations). Sediments from 450 $480 \mathrm{~cm}$ a.s.l. (sample R17-B2) are richer in insect remains. The beetle fauna is dominated by mesic tundra species (52\%) and species from typical and arctic tundra habitats (22\%), but also includes habitants of dry tundra $(12 \%)$. There are single remains of the meadow-steppe species, Coniocleonus sp. and the sedge-heath Morychus viridis. The sample R17-B1 $(520 \mathrm{~cm}$ a.s.1.) contains only remains of one typical tundra species and one species from dry tundra habitat (Table 3). The sediments from another nearby-situated section, $\mathrm{R} 17+30$ (R3 from $320 \mathrm{~cm}$ and $\mathrm{R} 2$ from $360 \mathrm{~cm}$ a.s.l.) also contain species from dry, arctic, mesic tundra and sedge heaths habitats (Table 3 ).

Two IRSL dates, $134 \pm 22 \mathrm{ka}$ (Lya-2, $500 \mathrm{~cm}$ a.s.1.) 


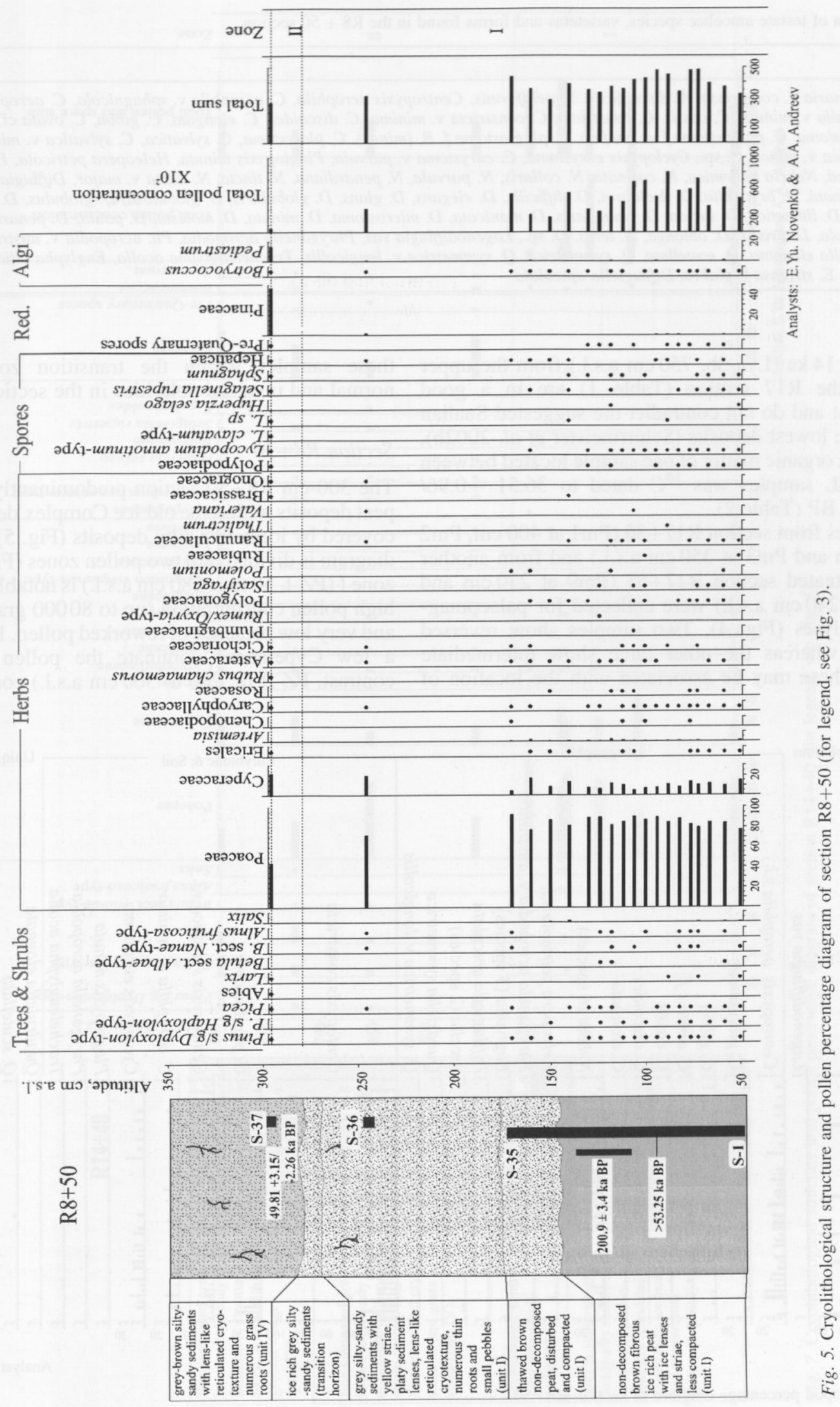


Table 4. List of testate amoebae species, varietetas and forms found in the $\mathrm{R} 8+50$ section.

\section{Taxa name}

Arcella arenaria v. compressa, A. discoides v. scutelliformis, Centropyxis aerophila, C. aerophila v. sphagnicola, C. aerophila v. grandis, C. aerophila v. minuta, $C$. cassis, $C$. constricta, $C$. constricta v. minima, $C$. discoides, $C$. elongata, $C$. gibba, $C$. ovata cf.,

C. plagiostoma, C. plagiostoma f. A (major), C. plagiostoma f. B. (minor), C. platystoma, C. sylvatica, C. sylvatica v. microstoma, C. sylvatica v. minor, C. sp., Cyclopyxis eurystoma, C. eurystoma v. parvula, Plagiopyxis minuta, Heleopera petricola, $H$. petricola v. amethystea, Nebela bohemica, N. carinata, N. collaris, N. parvula, N. penardiana, N. tincta, N. tincta v. major, Difflugia ampululla, D. acuminata, D. bryophila, D. decloitrei, D. difficilis, D. elegans, D. glans, D. globularis, D. globulosa, D. globulus, D. lanceolata, D. leidy, D. limnetica, D. lucida, D. mamillaris, D. manicata, D. microstoma, D. minuta, D. molesta, D. paulii, D. penardi,

D. petricola, D. pristis, D. oblonga, D. teres, D. sp., Lagenodifflugia vas, Phryganella acropodia, Ph. acropodia v. australica cf., Quadrulella elongata, Q. scutellata, Q. symmetrica, Q. symmetrica v. longicollis, Tracheleuglypha acolla, Euglypha ciliata f. glabra, E. laevis, E. strigosa f. glabra, Difflugiella apiculata

and $77 \pm 14 \mathrm{ka}$ (Lya-3b, $750 \mathrm{~cm}$ a.s.l.) from the upper part of the R17 section (Table 1) are in a good agreement and do not contradict the suggested Saalian age of the lowest deposits (Schirrmeister et al. 2002b). However, organic matter of one sample located between both IRSL samples was ${ }^{14} \mathrm{C}$ dated to $36.51+0.96 /$ $-0.86 \mathrm{ka}$ BP (Table 2).

Samples from section R17+30 (Pm1 at $400 \mathrm{~cm}, \mathrm{Pm} 2$ at $370 \mathrm{~cm}$ and $P m 3$ at $350 \mathrm{~cm}$ a.s.l.) and from another nearby-situated section $\mathrm{R} 17+85$ (Pm9 at $230 \mathrm{~cm}$ and $\mathrm{Pm} 10$ at $240 \mathrm{~cm}$ a.s.1.) were collected for palaeomagnetic analyses (Fig. 4). Two samples show reversed polarity, whereas the other three show intermediate values. These may be associated with the location of these samples within the transition zone between normal and reversed polarities in the section (Fig. 4).

\section{Section $R 8+50$}

The $300-\mathrm{cm} \mathrm{R} 8+50$ section predominantly consists of peat deposits within the old Ice Complex deposits and is covered by loess-like silty deposits (Fig. 5). The pollen diagram is divided into two pollen zones (Fig. 5). Pollen zone I (PZ-I, 50 to $c .280 \mathrm{~cm}$ a.s.l.) is notable for its very high pollen concentration (up to 80000 grains per $\mathrm{cm}^{3}$ ) and very low presence of reworked pollen. Poaceae with a few Cyperaceae dominate the pollen spectra. In contrast, PZ-II (c. 280 to $300 \mathrm{~cm}$ a.s.1.) consists of one

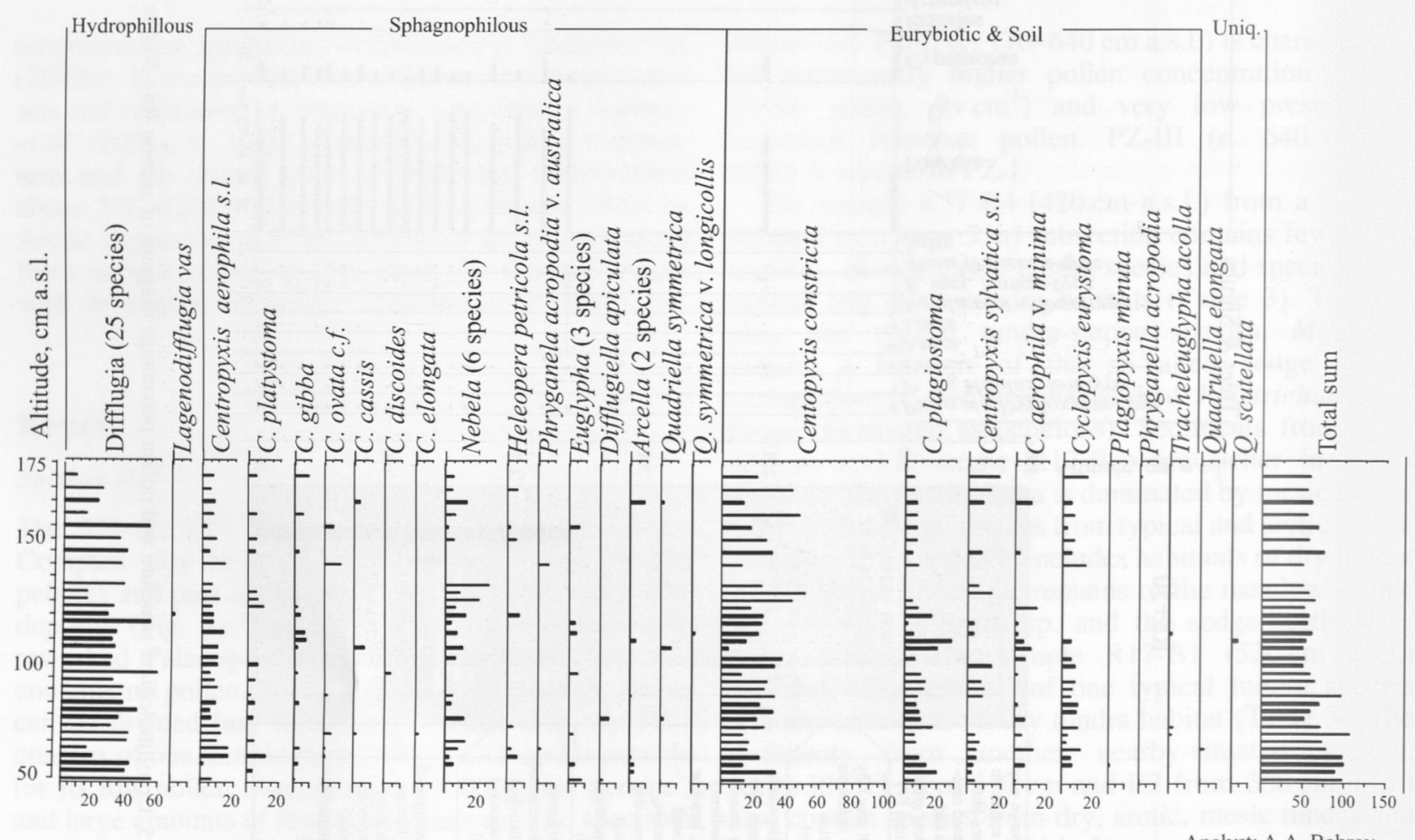

Fig. 6. Rhizopod percentage diagram of section $\mathrm{R} 8+50$. 


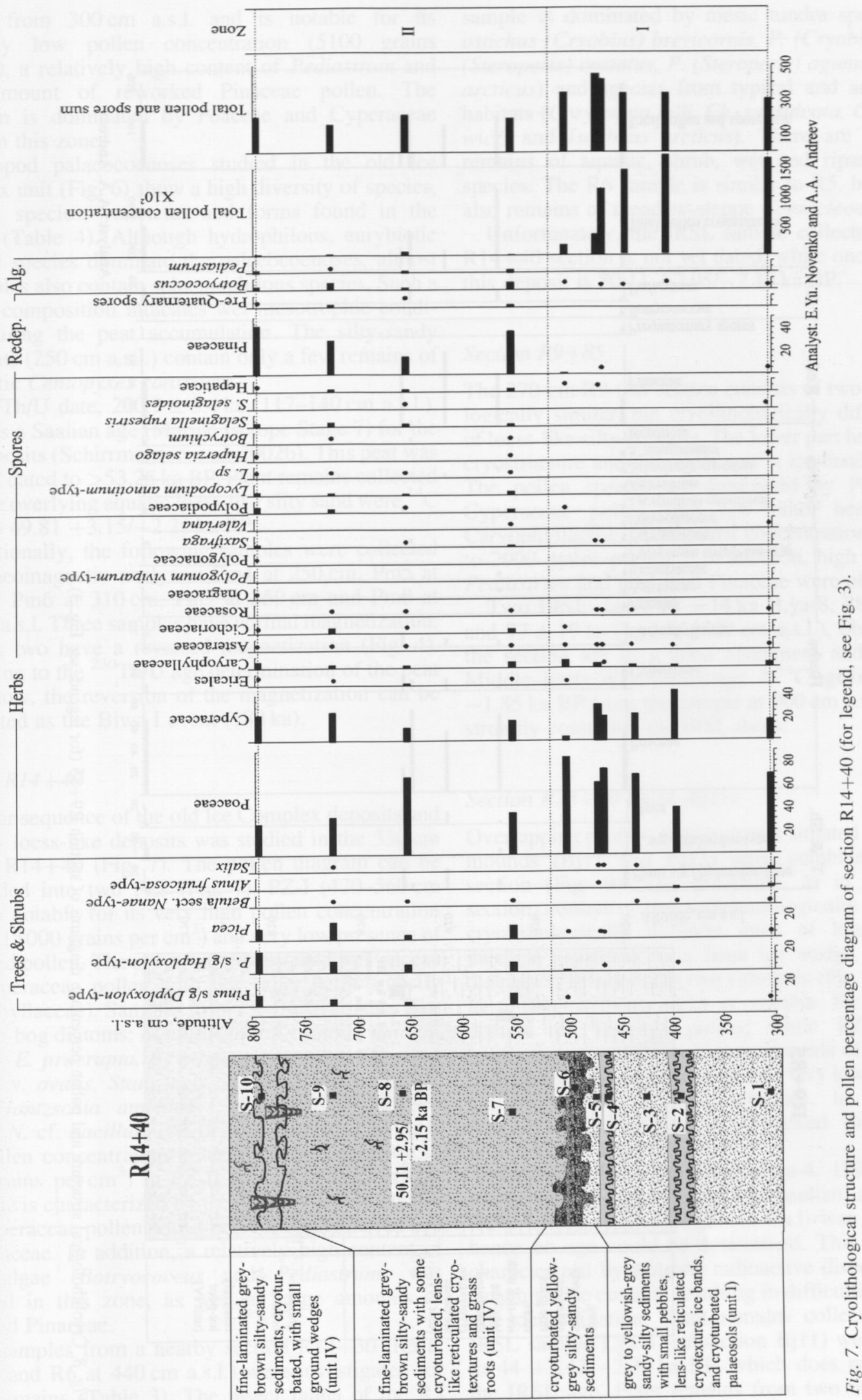




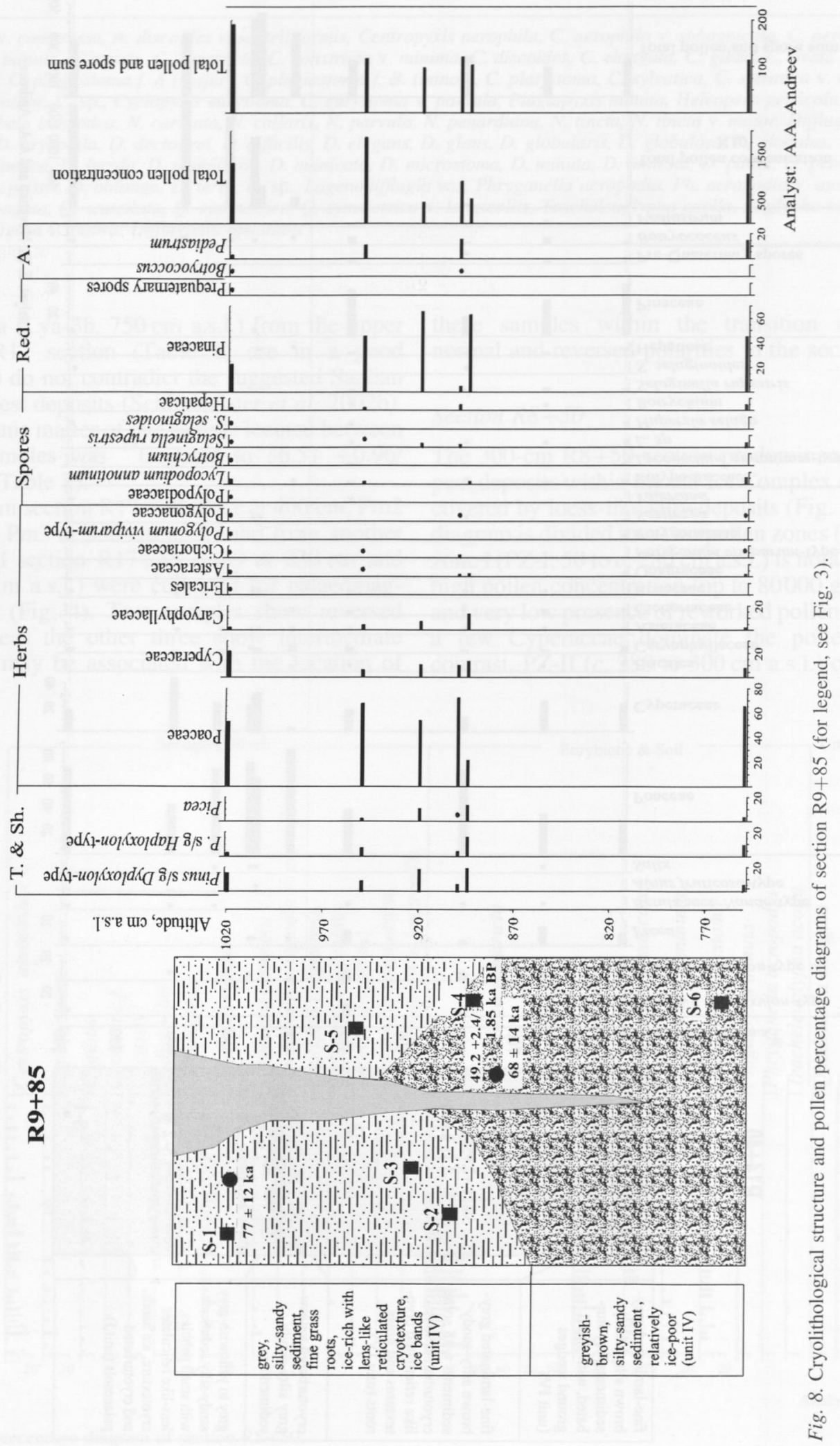


sample from $300 \mathrm{~cm}$ a.s.l. and is notable for its relatively low pollen concentration (5100 grains per $\mathrm{cm}^{3}$ ), a relatively high content of Pediastrum and large amount of reworked Pinaceae pollen. The spectrum is dominated by Poaceae and Cyperaceae pollen in this zone.

Rhizopod palaeocoenoses studied in the old Ice Complex unit (Fig. 6) show a high diversity of species, with 71 species, varietetas and forms found in the section (Table 4). Although hydrophilous, eurybiotic and soil species dominate the palaeocoenoses, almost all samples also contain sphagnophilous species. Such a species composition indicates wet mesotrophic conditions during the peat accumulation. The silty-sandy sediments $(250 \mathrm{~cm}$ a.s.1.) contain only a few remains of eurybiotic Centopyxes constricta.

A ${ }^{230} \mathrm{Th} / \mathrm{U}$ date, $200.9 \pm 3.4 \mathrm{ka}(117-140 \mathrm{~cm}$ a.s.l.), indicates a Saalian age (Marine Isotope Stage 7) for the peat deposits (Schirrmeister et al. 2002b). This peat was also ${ }^{14} \mathrm{C}$ dated to $>53.25 \mathrm{ka} \mathrm{BP}$. Plant remains collected from the overlying aquatic loess-like silty sand were ${ }^{14} \mathrm{C}$ dated to $49.81+3.15 /-2.26 \mathrm{ka}$ BP.

Additionally, the following samples were collected for palaeomagnetic analyses: $\mathrm{Pm} 4$ at $250 \mathrm{~cm}, \mathrm{Pm} 5$ at $280 \mathrm{~cm}, \mathrm{Pm} 6$ at $310 \mathrm{~cm}, \mathrm{Pm} 7$ at $350 \mathrm{~cm}$ and Pm8 at $420 \mathrm{~cm}$ a.s.l. Three samples have normal magnetization, whereas two have a reversed magnetization (Fig. 4). According to the ${ }^{230} \mathrm{Th} / \mathrm{U}$ age determination of the peat lens below, the reversion of the magnetization can be interpreted as the Biwa I event (180 ka).

\section{Section $\mathrm{R} 14+40$}

A similar sequence of the old Ice Complex deposits and aqueous loess-like deposits was studied in the $330 \mathrm{~cm}$ section R14+40 (Fig. 7). The pollen diagram can be subdivided into two PZs (Fig. 7). PZ-I $(470-560 \mathrm{~cm}$ a.s.l.) is notable for its very high pollen concentration (up to 115000 grains per $\mathrm{cm}^{3}$ ) and very low presence of reworked pollen. The spectra are dominated by Poaceae and Cyperaceae pollen with few other herbs (mostly Caryophyllaceae). Samples from PZ-1 also contain lake and lake-bog diatoms: Eunotia lunaris v. subarcuata, $E$. gracilis, E. praerupta, E. exigua, E. suecica, Diatoma vulagre v. ovalis, Stauroneis anceps, Pinnularia borealis, Hantzschia amphioxys, Navicula pupula, $N$. mutica, N. cf. bacillum (A. Bryantseva, pers. comm.). The pollen concentration is significantly lower (up to 7300 grains per $\mathrm{cm}^{3}$ ) in PZ-II (c. $520-800 \mathrm{~cm}$ a.s.l.). The zone is characterized by the dominance of Poaceae and Cyperaceae pollen with some Caryophyllaceae and Cichoriaceae. In addition, a relatively high content of green algae (Botryococcus and Pediastrum) was observed in this zone, as well as large amounts of reworked Pinaceae.

The samples from a nearby section $\mathrm{R} 14+30$ (R5 at $400 \mathrm{~cm}$ and R6 at $440 \mathrm{~cm}$ a.s.l.) were investigated for insect remains (Table 3). The insect fauna of the R5 sample is dominated by mesic tundra species (Pterostichus (Cryobius) brevicornis, P. (Cryobius) spp., $P$. (Steroperis) costatus, P. (Steroperis) agonus, Tachinus arcticus) and species from typical and arctic tundra habitats (Chrysolina tolli, Ch. subsulcata, Ch. wollosowiczi and Isochnus arcticus). There are also a few remains of aquatic, shrub, wet and riparian habitat species. The R6 sample is similar to R5, but there are also remains of meadow-steppe Coniocleonus sp.

Unfortunately, the IRSL sample collected from the $\mathrm{R} 14+40$ section is not yet dated, while one ${ }^{14} \mathrm{C}$ age of this deposit is $50.11+2.95 /-2.15 \mathrm{ka} \mathrm{BP}$.

\section{Section $R 9+85$}

The 270-cm R9+85 section consists of two sedimentologically similar, but cryolithologically different parts of loess-like silty deposits. The lower part has a massive cryostructure and the upper part is ice-banded (Fig. 8). The pollen spectra are dominated by Poaceae and Cyperaceae pollen with few other herbs (mostly Caryophyllaceae). The pollen concentration is low (up to 2000 grains per $\mathrm{cm}^{3}$ ). In addition, high amounts of Pediastrum and reworked Pinaceae were observed.

Two IRSL dates, $68 \pm 14 \mathrm{ka}$ (Lya-8, $880 \mathrm{~cm}$ a.s.l.) and $77 \pm 19 \mathrm{ka}$ (Lya-9, $1020 \mathrm{~cm}$ a.s.l.), obtained from the section are in a good agreement and point to a Middle-Early Weichselian age. A ${ }^{14} \mathrm{C}$ age of $49.2+2.4$ / $-1.85 \mathrm{ka}$ BP from the sample at $900 \mathrm{~cm}$ a.s.l. does not strongly contradict the IRSL dates.

\section{Section R18+50 (Bj11-Bj13)}

Overlapping profiles of two closely situated thermokarst mounds (Bj11 and Bj13) were combined into one section (Fig. 9). The sediments, as in the R9+85 section, consist of two sedimentologically similar, but cryolithologically different units of loess-like silty deposits separated by a large ice wedge. The pollen diagram is divided into two subzones (Fig. 9). The PZIa $(1190-1375 \mathrm{~cm}$ a.s.1.) is notable for the higher content of Poaceae pollen, while PZ-Ib (1375$1430 \mathrm{~cm}$ a.s.1.) contains higher amounts of Cyperaceae pollen. The pollen concentration is very low (up to 2600 grains per $\mathrm{cm}^{3}$ ) in both subzones. In addition, a relatively high content of reworked Pinaceae was observed in both subzones.

An IRSL date, $57 \pm 10 \mathrm{ka}$ (Lya-4, $1290 \mathrm{~cm}$ a.s.l.), shows the Zyryanian (Early Weichselian) age. Another IRSL sample (Lya-5, $1120 \mathrm{~cm}$ a.s.l) was not datable, hence no age could be determined. This sample was characterized by a strong radioactive disequilibria and very high ice content, resulting in difficulties with dose rate determination. Plant remains collected near the IRSL sample Lya-4 (subsection Bj11) were ${ }^{14} \mathrm{C}$ dated to $44+3.43 /-2.39 \mathrm{ka} \mathrm{BP}$, which does not contradict the IRSL age. Plant remains from two other samples 

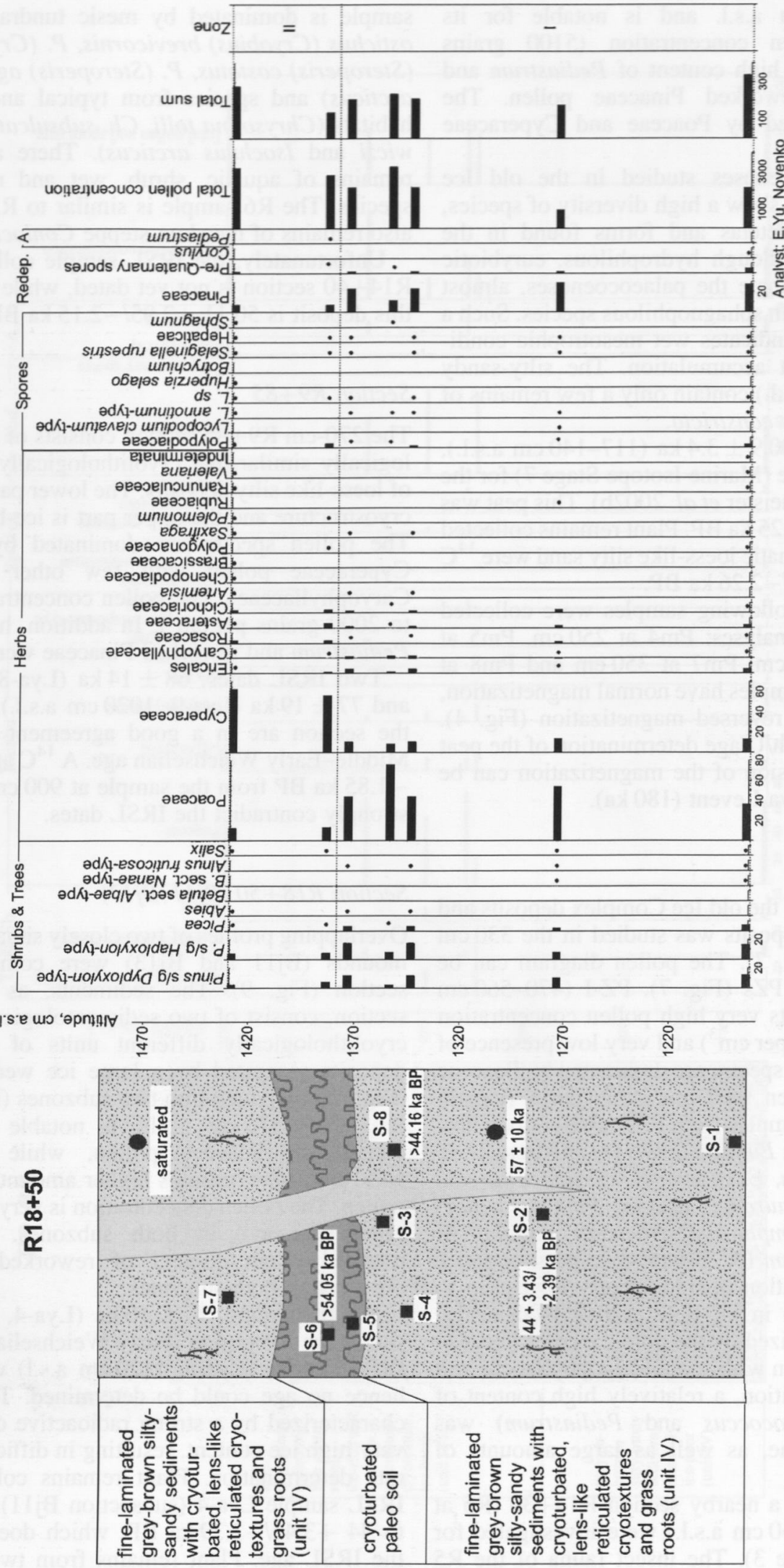


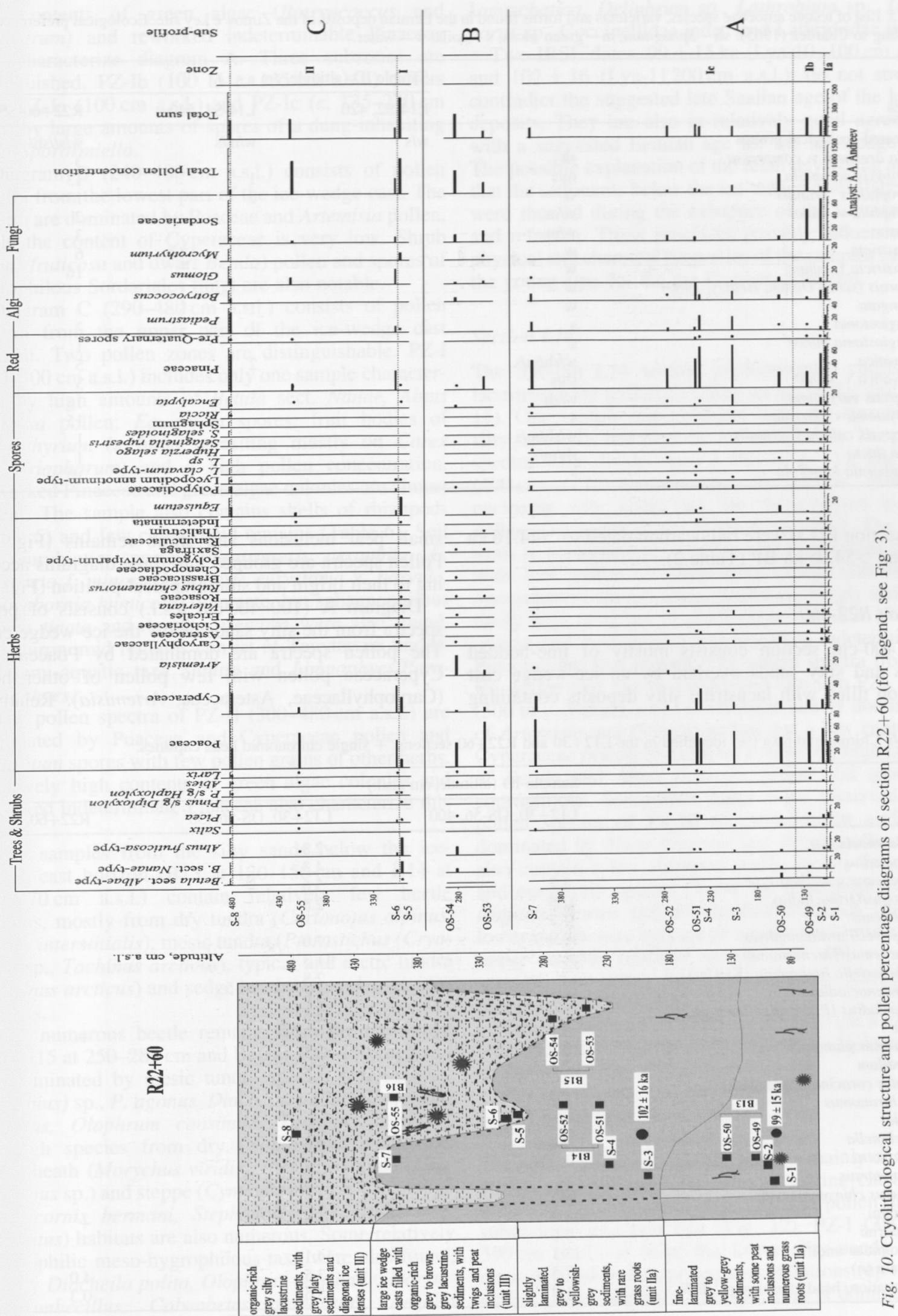


Table 5. List of testate amoebae species, varietetas and forms found in the Eemian deposits of the Zimov'e key site. Ecological preferences are according to Chardez (1965): sh - Sphagnum, m - green moss, s - soils, w - water.

\begin{tabular}{|c|c|c|c|c|}
\hline \multirow[b]{2}{*}{ Species } & & \multicolumn{3}{|c|}{ Sample ID (altitude, $\mathrm{cm}$ a.s.1.) } \\
\hline & & L14-S2, 420 & L14-S4, 540 & $\mathrm{R} 22+60-\mathrm{S} 5,300$ \\
\hline Dominated ecological groups & & $\mathrm{w} / \mathrm{s}$ & $\mathrm{w} / \mathrm{m} / \mathrm{s}$ & $\mathrm{w} / \mathrm{s} / / \mathrm{sh} /$ \\
\hline Arcella arenaria v. compressa & $\mathrm{sh}$ & & & 3 \\
\hline Centropyxis aerophila & $\mathrm{m} / \mathrm{s}$ & & 1 & 13 \\
\hline C. aerophila v. grandis & w & & 2 & 1 \\
\hline C. aerophila v. minor & $\mathrm{w} / \mathrm{m}$ & & & 2 \\
\hline C. cassis & $\mathrm{w} / \mathrm{m}$ & & & 3 \\
\hline C. constricta & w & 2 & & 6 \\
\hline C. constricta f. minor & w & & & 16 \\
\hline C. ecornis (sensu Ogden, Hedley, 1980) & w & 2 & & \\
\hline C. elongata & w & & 1 & \\
\hline C. plagiostoma & $\mathrm{s}$ & 2 & 1 & 2 \\
\hline C. plagiostoma minor & $\mathrm{s}$ & & & 1 \\
\hline C. sylvatica & $\mathrm{w} / \mathrm{sh} / \mathrm{m} / \mathrm{s}$ & & 2 & 5 \\
\hline C. sylvatica v. minor & $\mathrm{sh} / \mathrm{s}$ & & & 3 \\
\hline Cyclopyxis eurystoma & $\mathrm{w} / \mathrm{sh}$ & & & 16 \\
\hline C. eurystoma v. parvula & $\mathrm{s}$ & & & 15 \\
\hline Plagiopyxis callida f. grandis & $\mathrm{w} / \mathrm{sh} / \mathrm{m} / \mathrm{s}$ & & & 1 \\
\hline Nebela tincta & $\mathrm{sh} / \mathrm{m} / \mathrm{s}$ & & & 1 \\
\hline Schoenbornia humicola & s & & & 10 \\
\hline
\end{tabular}

(subsection $\mathrm{Bj} 13$ ) were radiocarbon dated to $>44.16 \mathrm{ka}$ $\mathrm{BP}$ and $>54.05 \mathrm{ka} \mathrm{BP}$ (Table 2).

\section{Section $R 22+60$}

The $400-\mathrm{cm}$ section consists mostly of fine-bedded sands and silty sands overlaid by an ice-wedge cast horizon filled with lacustrine silty deposits containing small peat inclusions and shrub remains (Fig. 10). Pollen spectra are grouped into three diagrams according to their origin and stratigraphical position (Fig. 10).

Diagram A (100-400 cm a.s.l.) consists of pollen spectra from the silty sands below the ice-wedge casts. The pollen spectra are dominated by Poaceae and Cyperaceae pollen with few pollen of other herbs (Caryophyllaceae, Asteraceae, Artemisia). Relatively

Table 6. Chironomid taxa (\%) identified in the L12+30 and R22+60 sections. + single chironomid head capsules.

\begin{tabular}{|c|c|c|c|}
\hline \multirow[b]{2}{*}{ Taxa } & \multicolumn{3}{|c|}{$\underline{\text { Sample ID (altitude, } \mathrm{cm} \text { a.s.l.) }}$} \\
\hline & $\mathrm{L} 12+30, \mathrm{OS}-56,400$ & $\mathrm{~L} 12+30$, OS-56,430 & $\mathrm{R} 22+60, \mathrm{~S}-5,300$ \\
\hline Bryophaenocladius & & 2.8 & \\
\hline Chaetocladius & & 4.3 & \\
\hline & $\begin{array}{l}1.7 \\
26\end{array}$ & $\begin{array}{r}5.6 \\
2.8\end{array}$ & \\
\hline $\begin{array}{l}\text { Cricotopus/Orthocladius } \\
\text { Hydrobaenus }\end{array}$ & $\begin{array}{l}2.6 \\
1.7\end{array}$ & 2.8 & \\
\hline $\begin{array}{l}\text { Hydrobaenus } \\
\text { Limnophyes/Paralimnophyes }\end{array}$ & $\begin{array}{r}1.7 \\
13.9\end{array}$ & 17.0 & + \\
\hline Metriocnemus/Thienemannia & & 11.3 & \\
\hline Parakiefferiella bathophila (Kieffer) & & 2.8 & \\
\hline Paraphaenocladius & 6.1 & 5.6 & \\
\hline Psectrocladius (P.) sordidellus-type & 0.9 & 2.8 & \\
\hline Smittia & 5.2 & & + \\
\hline Chironomus plumosus-type & 12.2 & 8.5 & \\
\hline Polypedilum & 1.7 & 2.8 & \\
\hline Sergentia coracina (Zetterstedt) & 1.7 & & \\
\hline Stictochironomus & 3.5 & & \\
\hline Zavrelia & 3.5 & 2.8 & \\
\hline Stempellinella & 2.6 & 5.6 & \\
\hline Micropsectra & 3.5 & & \\
\hline Paratanytarsus & & 2.8 & \\
\hline $\begin{array}{l}\text { Tanytarsus chinyensis-type } \\
\text { Tanytarsini }\end{array}$ & $\begin{array}{r}5.2 \\
139\end{array}$ & $\begin{array}{l}2.8 \\
5.6\end{array}$ & + \\
\hline Pentaneurini & 7.0 & 5.6 & \\
\hline Chironomidae undiff. & 13.1 & 14.1 & \\
\hline Total sum $(n)$ & 57.5 & 53.5 & 4.0 \\
\hline Concentration, head capsules $\mathrm{g}^{-1}$ DW & 31.9 & 5.5 & 0.3 \\
\hline
\end{tabular}


high contents of green algae (Botryococcus and Pediastrum) and reworked indeterminable Pinaceae also characterize diagram A. Three subzones are distinguished, $\mathrm{PZ}-\mathrm{Ib}$ (100 to $c$. $135 \mathrm{~cm}$ a.s.l.) differs from PZ-Ia $(100 \mathrm{~cm}$ a.s.1.) and PZ-Ic (c. $135-270 \mathrm{~cm}$ a.s.1.) by large amounts of spores of a dung-inhabiting fungi Sporormiella.

Diagram B (240-400 cm a.s.l.) consists of pollen spectra from the lowest part of the ice-wedge cast. The spectra are dominated by Poaceae and Artemisia pollen, while the content of Cyperaceae is very low. Shrub (Alnus fruticosa and dwarf Betula) pollen and spores of coprophilous Sordariales fungi are also notable.

Diagram C (290-480 cm a.s.l.) consists of pollen spectra from the upper part of the ice-wedge cast horizon. Two pollen zones are distinguishable. PZ-I (290-300 cm a.s.1.) includes only one sample characterized by high amounts of Betula sect. Nanae, Alnus fruticosa pollen; Equisetum spores, fruit bodies of Mycrothyrium (a fungi parasiting mostly on Carex and Eriophorum) and a high pollen concentration. Reworked Pinaceae and green algae colonies are almost absent. The sample also contains shells of rhizopods (Table 5) and few chironomid remains (Table 6). Soil and eurybiotic species (Centropyxis aerophila, $C$. constricta f. minor, Cyclopyxis eurystoma v. parvula, Schoenbornia humicola) dominate, but sphagnophilous Nebela tincta and Arcella arenaria were also found. The chironomid remains consist of Tanytarsini undiff. and semi-aquatic taxa Smittia and Limnophyes/Paralimnophyes.

The pollen spectra of PZ-II $(300-480 \mathrm{~cm}$ a.s.1.) are dominated by Poaceae and Cyperaceae pollen and Equisetum spores with few pollen grains of other herbs. Relatively high contents of green algae colonies and reworked indeterminate Pinaceae also characterize this zone.

The samples from the silty sands below the icewedge cast horizon (B13 at $120-150 \mathrm{~cm}$ and B14 at $240-270 \mathrm{~cm}$ a.s.1.) contain relatively few beetle remains, mostly from dry tundra (Curtonotus alpinus, Amara interstitialis), mesic tundra (Pterostichus (Cryobius) sp., Tachinus arcticus), typical and arctic tundra (Isochnus arcticus) and sedge heath (Morychus viridis) habitats.

The numerous beetle remains from the ice-wedge cast (B15 at $250-280 \mathrm{~cm}$ and B16 at $400-430 \mathrm{~cm}$ a.s.1.) are dominated by mesic tundra species (Pterostichus (Cryobius) sp., P. agonus, Diacheila polita, Cholevinus sibiricus, Olophrum consimile, Tachinus arcticus), although species from dry (Notiophilus aquaticus), sedge heath (Morychus viridis), meadow-steppe (Coniocleonus sp.) and steppe (Cymindis arctica, Chrysolina brunnicornis bermani, Stephanocleonus eruditus, S. fossulatus) habitats are also numerous. Some relatively thermophilic meso-hygrophilous taxa were also found, namely Diacheila polita, Olophrum consimile, Dorytomus imbecillus, Colymbetes dolabratus, Aegalia kamtschatica, Deliphrum sp., Lathrobium sp., Tachyporus sp., Coccinellidae indet. and Lathridiidae indet.

Two IRSL dates, $99 \pm 15 \mathrm{ka}$ (Lya-10, $100 \mathrm{~cm}$ a.s.l.) and $102 \pm 16$ (Lya-11 $200 \mathrm{~cm}$ a.s.l.), do not strongly contradict the suggested late Saalian age of the lowest deposits. They are also in relatively good agreement with a suggested Eemian age for the ice-wedge cast. The possible explanation of the relatively young ages is that the sediments below the ice-wedge casts (taberites) were thawed during the existence of the Eemian lake and refrozen. These processes possibly influenced the physical and chemical properties of the samples causing the young ages for the pre-Eemian sediments.

\section{Section $L 14$}

The $350-\mathrm{cm} \mathrm{L14}$ section predominantly consists of lacustrine silty sediments filling an ice-wedge cast (Fig. 11). One sample was collected from the surrounding silty sands, the rest from the ice-wedge cast. The pollen spectra were divided into 3 PZs (Fig. 11). The PZ-I $(400 \mathrm{~cm}$ a.s.1.) includes only the sample from the enclosing silty sands that are characterized by low pollen concentration (2300 grains per $\mathrm{cm}^{3}$ ). The spectrum is dominated by Poaceae and Cyperaceae pollen with few pollen of other herbs. Large amounts of Sporormiella spores (dung-inhabiting fungi) and relatively high contents of green algae colonies (Botryococcus and Pediastrum) and reworked indeterminable Pinaceae are also present. The pollen spectra from the ice-wedge cast can be subdivided into two PZs. PZ-II (300 to c. $360 \mathrm{~cm}$ a.s.1.) is distinguished by domination of Artemisia and Poaceae pollen and a low content of Cyperaceae pollen. In addition, a relatively high amount of Betula and Alnus fruticosa pollen and spores of coprophilous Sordariales fungi were observed. The pollen spectra of PZ-III (c. $360-540 \mathrm{~cm}$ a.s.l.) are dominated by Alnus fruticosa and Betula pollen. They also contain a few rhizopod shells, mostly from soils and eurybiotic species (Table 5). Hydrophilous Centropyxis ecornis and unidentified ostracods from the lower sample may indicate an aquatic environment. The upper sample contains mostly soil and eurybiotic species, but moss and soil habitant, Centropyxis elongata, is also present.

Two ${ }^{14} \mathrm{C}$ ages of $>50420 \mathrm{yr}$ BP $(420 \mathrm{~cm}$ a.s.l. $)$ and $>50880 \mathrm{yr} \mathrm{BP}(540 \mathrm{~cm}$ a.s.l. $)$ confirm pre-Holocene age of the sediments.

\section{Section $L 12+30$}

The 430-cm L12+30 section consists mainly of an icewedge cast horizon filled with lacustrine clayey silt, underlain by silty sands (Fig. 12). The pollen diagram subdivided into two PZs (Fig. 12). PZ-I (350 to $c$. $390 \mathrm{~cm}$ a.s.l.) is from the lower silty sands and is characterized by low pollen concentrations (up to 1200 pollen grains per $\mathrm{cm}^{3}$ ). The spectrum is dominated by 


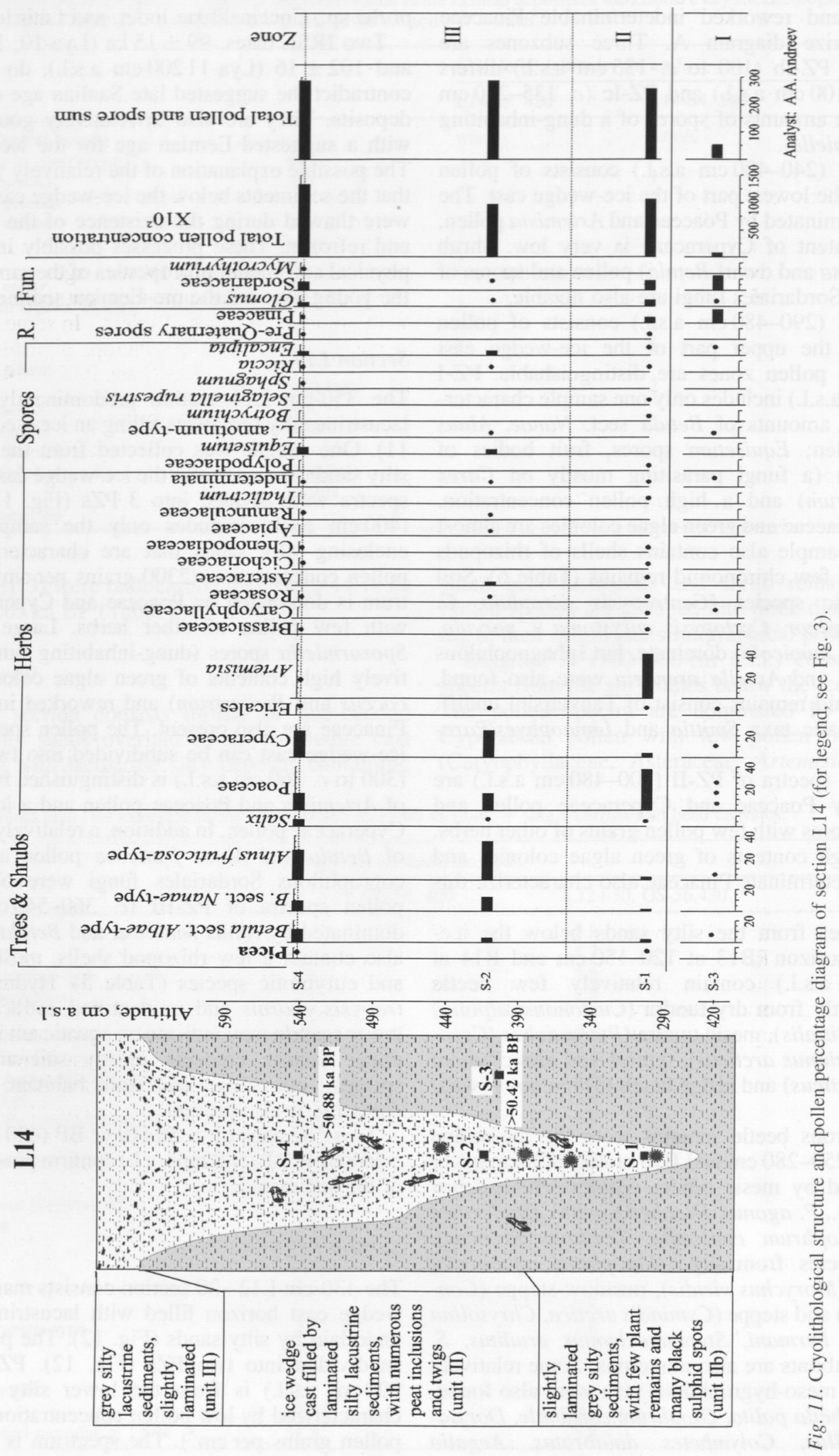


Poaceae and Cyperaceae pollen with few pollen of other herbs. Large amounts of Sporormiella spores from dung-inhabiting Sordariales fungi and relatively high contents of green algae colonies (Botryococcus and Pediastrum) and reworked indeterminable Pinaceae are also characteristic for the spectrum. The pollen spectra from the ice-wedge cast can also be subdivided into two subzones. The pollen spectra are dominated by Alnus fruticosa and Betula pollen with a rather high pollen concentration (5100-14600 grains per $\left.\mathrm{cm}^{3}\right)$ in both subzones. The lower subzone (c. 390-550 cm a.s.1.) is notable for a higher content of Salix, while the upper subzone displays a higher content of Artemisia and Poaceae.

The sample from $400 \mathrm{~cm}$ a.s.l. contained numerous caddis fly (Trichoptera) remains and chironomid head capsules (Table 6). The sample from $430 \mathrm{~cm}$ a.s.l. contained only few caddis fly remains and concentration of chironomids is significantly lower. In both samples the chironomid head capsules are well preserved and identified to 22 taxonomic groups (Table 6). The assemblages are characterized by a high percentage $(25-41 \%)$ of semi-aquatic Smittia, Limnophyes/Paralimnophyes, Chaetocladius, Bryophaenocladius, Paraphaenocladius and Metriocnemus/Thienemannia associated with moss habitats. The littoral thermophilous taxa (Cricotopus/Orthocladius, Zavrelia, Psectrocladius sordidellus-type, Tanytarsus chinyensis-type, Stempellinella, Polypedilum, Corynoneura, Hydrobaenus, Pentaneurini) associated with aquatic macrophytes are also numerous (25-27\%). The thermophilous taxon, Chironomus plumosus-type dominates $(8-12 \%)$ in the sublittoral/profundal group. Only a few indeterminable chironomid remains have been found in the sample from $700 \mathrm{~cm}$ a.s. 1 .

The deposits below the ice-wedge casts (B18 at 350$380 \mathrm{~cm}$ a.s.1.) contain a few beetle remains from different habitats (Table 3). The lacustrine silts (B17 at $400-430 \mathrm{~cm}$ and B19 at $700-730 \mathrm{~cm}$ a.s.1.) contain numerous beetle remains, mostly mesic tundra species (up to $45 \%$ ), but species from dry tundra (up to $19 \%$ ) and steppe (including sedge heath habitats) are also numerous. Typical riparian and aquatic species are common (up to $10 \%$ and $8 \%$, respectively) as well. Some relatively thermophilic species, such as Pelophila borealis and Olophrum consimile, have also been found.

\section{Discussion: palaeoenvironmental reconstructions}

The most important result of this study is the clear evidence of humid and warm (interglacial) palaeoenvironmental conditions during an interval significantly older than the Holocene. This interval is most likely the Kazantsevo (Eemian) stage. Most of the age determinations, as well as the palaeoecological studies of the surrounding deposits, support this interpretation. The palaeoecological evidences of interglacial conditions were found in ice-wedge casts and lacustrine deposits (unit III). Organic remains in the ice-wedge casts were ${ }^{14} \mathrm{C}$ dated to minimal ages. The loess-like flood-plain deposits of units IIa and IV enclose the Eemian lake deposits of unit III.

Sediments of unit IIa were IRSL dated to $102 \pm 16$ and $99 \pm 15 \mathrm{ka}$ (Table 1). The deposits of unit IV were IRSL dated between $77 \pm 14$ and $57 \pm 10 \mathrm{ka}$. There are also ${ }^{14} \mathrm{C}$ dates from unit IV with ages younger than the IRSL dates from the same unit, but there are also dates with minimal ${ }^{14} \mathrm{C}$ ages (Table 2 ). In some profiles from the central part of the outcrop, a disturbed horizon above unit I is noticeable. In the R17 profile it was IRSL dated to $134 \pm 22 \mathrm{ka}$. This horizon is probably a sign of local hiatuses between unit I and unit IV, indicating the patch-like sedimentation during the Eemian. In general, units II and IV strongly differ from the Ice Complex of unit $\mathrm{V}$ in their facies properties.

Based on the radiocarbon ages, Meyer et al. (2002b) suggested that the loess-like flood-plain deposits rapidly accumulated at around $50 \mathrm{ka}$ BP. It was assumed that there is a sedimentation hiatus of about 150 ka between unit I and the flood-plain deposits. The new IRSL ages clearly show that the postulated hiatus occurred locally and was much shorter in duration. In contrast to the Bykovsky Peninsula outcrops (Schirrmeister et al. 2002a; Meyer et al. 2002a; Andreev et al. 2002a; Bobrov et al. 2004), where a continuous sequence of one depositional unit (Late Pleistocene Ice Complex) is preserved, the studied outcrops on Bol'shoy Lyakhovsky Island represent a discontinuously formed sequence of permafrost deposits covering a much longer time period.

TL ages of unit I and II obtained by Arkhangelov et al. (1996) and Arkhangelov (pers. comm.) are certainly over the limit of the TL method for sediments of this kind (Table 7). On the contrary, the TL ages from unit II (Kunitsky et al. 2000) and from units III and IV (A. A. Arkhangelov, pers. comm.) fit quite well within the age range of interest in this paper. Insufficient bleaching of the sediments during accumulation is a major problem for thermoluminescence age determinations, and hence can cause geochronological confusion. This may quite certainly be excluded for the IRSL dating, as bleaching of the measured signal is faster and more effective. The plateau tests carried out on these samples indicate sufficient bleaching. Thus, it is assumed that the resetting of the IRSL signal of these deposits was complete during the transport and accumulation process.

\section{Facies development}

Geochronological studies of deposits older than the range of the radiocarbon method are still in progress, 


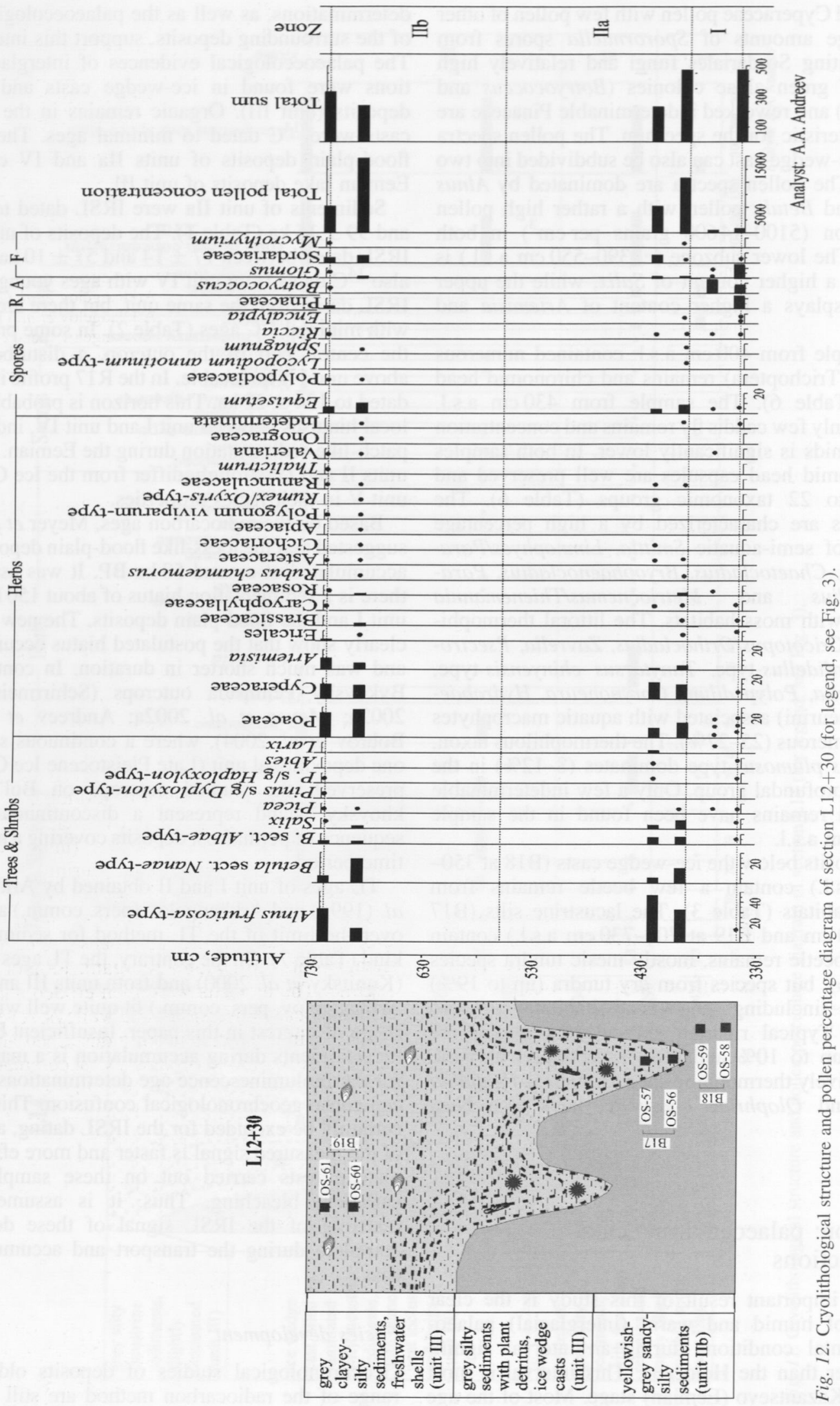


Table 7. Thermoluminescence ages from previous studies on the Bol'shoy Lyakhovsky Island.

\begin{tabular}{llcl}
\hline Lab. no. & Unit, profile (altitude a.s.l., m) & Age (ka) & Source \\
\hline RTL-821 & Unit II, R16+70, 1.7 & $35 \pm 10$ & Kunitsky (1998) \\
RTL-822 & Unit II, R17+70,2 & $36 \pm 10$ & Kunitsky (1998) \\
RTL-741 & Unit IIb, L9, 4.1 & $61 \pm 15$ & Kunitsky (1998) \\
RTL-740 & Unit IIb, R23+40, 5 & $96 \pm 26$ & Kunitsky et al. (2000) \\
RTL-742 & Unit II, R23+40,2 & $114 \pm 28$ & Kunitsky et al. (2000) \\
RTL-755 & upper Unit IV, R04+10, 25 & $57 \pm 15$ & Arkhangelov (pers. comm. 1998) \\
RTL-757 & lower Unit IV, R07, 6.6 & $110 \pm 28$ & Arkhangelov (pers. comm. 1998) \\
RTL-758 & lower Unit IV, R07? & $113 \pm 28$ & Arkhangelov (pers. comm. 1998) \\
RTL-753 & lower Unit IV, R11+70,16 & Arkhangelov (pers. comm. 1998) \\
RTL-756 & Unit III, R8, 12 & $122 \pm 30$ & Arkhangelov (pers. comm. 1998) \\
RTL-754 & Unit II, R7+10, 8 & $136 \pm 30$ & Arkhangelov et al. (1996) \\
RTL-750 & Unit I, R7+60, 2-2.5 & $360 \pm 90$ & Arkhangelov et al. (1996) \\
RTL-751 & Unit I, R7+60, 4.5 & Arkhangelov (pers. comm. 1998) \\
RTL-752 & Unit I, R7+60, 1-1.5 & $950 \pm 250$ & Arkhangelov et al. (1996) \\
\hline
\end{tabular}

especially for permafrost deposits. Therefore, difficulties with age determinations cannot be excluded. The ${ }^{14} \mathrm{C}$ ages presented in Table 2 reflect the Late Pleistocene (non-Holocene) age of the studied deposits. Based on ${ }^{14} \mathrm{C}$ ages of around $50 \mathrm{ka}$ BP obtained from grass roots from the aquatic loess-like deposits (unit IV), it is proposed that during the Early Weichselian sedimentological facies developed similar to the preEemian one. There are, however, no simple explanations for the younger ${ }^{14} \mathrm{C}$ ages. Possibly, they were caused by contamination during cryoturbation and thermokarst processes.

In general, a complex differentiation of the permafrost facies during the different stages of palaeolandscape development is suggested. This results in the coexistence of older and younger units (sedimentary bodies) at the same altitudes, or even the presence of older deposits at higher levels than younger sediments nearby. The suggested reasons are local erosion and further accumulation by thermokarst and thermoerosion as well as by fluvial processes. Observations of modern permafrost landscapes in the area indicate that relief strongly varies within short distances. Various periglacial forms (e.g. alas depressions, thermokarst lakes, thermoerosional valleys, small rivers and Ice Complex remains) coexist within a distance of a few hundred metres or less. A similar situation is postulated for the area during the Pleistocene, especially for the interstadial periods. During such periods, accumulation often takes place in depressions only, whereas on elevated areas erosion occurs or stable surfaces are formed. This pattern produces a patch-like sedimentation with local hiatuses. Additional factors causing a complicated geology are the strongly dislocated preQuaternary basement as well as neotectonic activities in the region. The proposed stages of landscape development in the area are presented below.

1. In the early Pleistocene, the basement was covered by a thick layer of so-called cryogenic elluvium (deposits of periglacially reworked Palaeogene weathering crust).

2. During the Middle Pleistocene (Saalian) the palaeorelief formed by basement structures was filled with old Ice Complex deposits (unit I), resulting in the formation of a relatively flat plain without strong geomorphological differences.

3. The overlying loess-like silty sands of unit II reflect a change of the facies. It is proposed that both subunits ( $a$ and $b$ ) were accumulated on a flood-plain with shallow lakes at the end of the Taz (Saalian) time. The local stratigraphical name of these deposits is the Kuchchugui Suite.

4. During the Eemian (Kazantsevo) stage, ice wedges of unit II were thawed due to thermokarst processes. The thermokarst depressions were subsequently filled with lacustrine deposits (unit III). Strong erosion processes took place during this stage. A frequently observed reworking horizon covering the ice wedges of the old Ice Complex unit reflects this erosion, which was probably caused by seismotectonical events provoking a reorganization of the runoff regime. The deposits were then eroded and redeposited in local depressions and valleys several times, resulting in the facies nesting described above.

5. Loess-like deposits of unit IV accumulated at the beginning of the Zyryanian (Early Weichselian) stage. These deposits are sedimentologically similar to the pre-Eemian unit IIa (they differ in their icebanded cryostructure and the absence of peat inclusions) and they probably consist of reworked material from unit IIa.

\section{The Saalian (Taz) environment}

The age of the lowermost unit $\mathrm{I}$ is still indistinct. According to the ${ }^{230} \mathrm{Th} / \mathrm{U}$ date from the $\mathrm{R} 8+50$ section, peat accumulated c. $200 \mathrm{ka} \mathrm{BP}$. This age seems to be reliable, as frozen peat is a closed system for uranium 
and thorium (Schirrmeister et al. 2002a). It is also in good agreement with the upper Middle Pleistocene age suggested by Romanovskii (1958b). On the contrary, the TL dates obtained by Arkhangelov from unit I (Table 7) are not reliable, since they are far beyond the TL dating range limit for these kinds of sediments. TL ages up to $300 \mathrm{ka}$ are reliable only for polymineralic fine-grained samples (Zöller et al. 1988; Shingvi et al. 1989). Although TL ages up to $400 \mathrm{ka}$ are possible for coarse-grained potassium feldspar samples, large errors occur for ages older than $120 \mathrm{ka}$ (Mejdahl 1988; Huett \& Jaeck 1989).

Palaeomagnetic investigations showed that samples from the lowermost unit I are reversal magnetized. Arkhangelov et al. (1996) believes that it is the Jaramillo reversal event in the early Pleistocene. However, according to the ${ }^{230} \mathrm{Th} / \mathrm{U}$ date, it can be attributed to the Biwa I reversal event (c. 179-189 ka BP; Nowaczyk \& Antonow 1997).

A middle Saalian stadial (?). - The oldest pollen spectrum from the studied deposits is PZ-I of R17 (Fig. 3 ), directly above the periglacially reworked remains of the weathering crust. It reflects sparse grass-sedge vegetation cover during this time. Relatively high contents of Asteraceae and Cichoriaceae, as well as large amounts of reworked pollen, indicate the presence of disturbed soils and erosion of older deposits. Therefore, the reflected severe interval can be assigned to a stadial during the middle Saalian time.

An interstadial c. 200-170(?) ka. - Pollen spectra from the PZ-II of R17 (Fig. 3), PZ-I of R8+50 (Fig. 5) and PZ-I of R14+40 (Fig. 7) sections indicate that dense grass-sedge tundra occupied the area after the severe stadial time reflected in the lowest part of section R17. Absence of typical cryoxerophitic taxa, high pollen concentrations and low amounts of redeposited pollen and spores indicate relatively warm and wet summers, probably similar to (or even warmer than) modern ones.

Rhizopod remains from the old Ice Complex deposits of section R8+50 (Fig. 6, Table 4) are numerous and reflect a high taxa diversity ( 71 species, varietetas and forms). The modern species diversity in the high Arctic is lower. For example, only 45 taxa are found in the modern habitats of Barents and Kara Seas coasts (Beyens et al. 2000). The relatively well-investigated rhizopod fauna of Spitzbergen consists of 48 taxa (Balik 1994). The high species diversity in the $R 8+50$ section may reflect a climate more favourable for the rhizopods than today's climate on the island. The rather stable contents of palaeocoenoses in peat indicate a relatively stable hydrothermal regime during the peat accumulation. A find of rare Quadrulella species is particularly interesting. These species were previously not reported from the region. Q. elongata is found only in Belgium and Venezuela, while $Q$. scutellata was only reported from North America (Chardez 1967), hence their presence in the Saalian sediments shows that the distribution of these rare species was significantly different from today.

Generally, pollen spectra of unit I are similar to the pollen spectra from the upper part of the so-called Kuchchugui suite. They accumulated in the vicinity of the Laptev Sea coast during the end of the Middle Pleistocene, and at some southern localities before the last interglacial (e.g. Barkova 1970a, 1982). According to Barkova (1970a, 1990), treeless grass-dominated vegetation prevailed in the Laptev Sea region during late Kuchchugui time.

The beetle fauna of the old Ice Complex sediments ( $\mathrm{R} 17, \mathrm{R} 17+30$ and $\mathrm{R} 14+30$ sections) is dominated by mesic tundra species and species from typical and arctic tundra habitats. The typical tundra-steppe beetles are almost absent in the sediments. Only a few remains of Coniocleonus sp. and Morychus viridis, which are common in Late Pleistocene deposits and occur in modern dry tundra habitats, were found (Kuzmina 2002).

Therefore, based on pollen, insect and rhizopod records, it is assumed that this interval during the middle Saalian time is an interstadial with relatively warm and wet summers compared to modern conditions. Tundra habitats ecologically similar to modern ones dominated the area. However, stable isotopes from the ice wedges sampled in section R17 suggest severe winter conditions during that time (Meyer et al. 2002b).

It is difficult to estimate the age of the interstadial. Taking into consideration the stratigraphical sequence, the IRSL and ${ }^{230} \mathrm{U} / \mathrm{Th}$ dates and the comparison of the pollen records with the published late Kuchchugui ones, a Saalian age for the lowest stadial and interstadial sediments is assumed. Alternatively, according to Arkhangelov et al. (1996) and Sher et al. (2002), these sediments may have accumulated during the late Pliocene/early Pleistocene. To accept their point of view, it must be assumed that there is a continuous hiatus between these early Pleistocene sediments and the overlying Middle/Late Pleistocene sediments. This hiatus must be several hundreds of thousands of years long. However, the existence of such a hiatus requires evidence. It is likely that only palaeontological remains, if they can be found in situ, would help to determine the age of the sediment.

It is also difficult to estimate the duration of the interstadial, but if we take into consideration as an example the duration of the Karginsky (Middle Weichselian) interstadial in Northern Siberia (e.g. Isaeva 1984; Lozhkin 1987; Anderson \& Lozhkin 2001; Andreev et al. 2002a, b), it may have lasted c. $30 \mathrm{ka}$ and ended $c .170 \mathrm{ka}$ BP or earlier. Gavrilov \& Tumskoy (2001) also suggested that a relatively warm interval in northern Yakutia during the Middle Pleistocene ended about 170 (190) ka BP.

A late Saalian (Kuchchugui) stadial c. 170(?)-130 ka. - The pollen spectra from PZ-III of R17 (Fig. 3), PZ- 


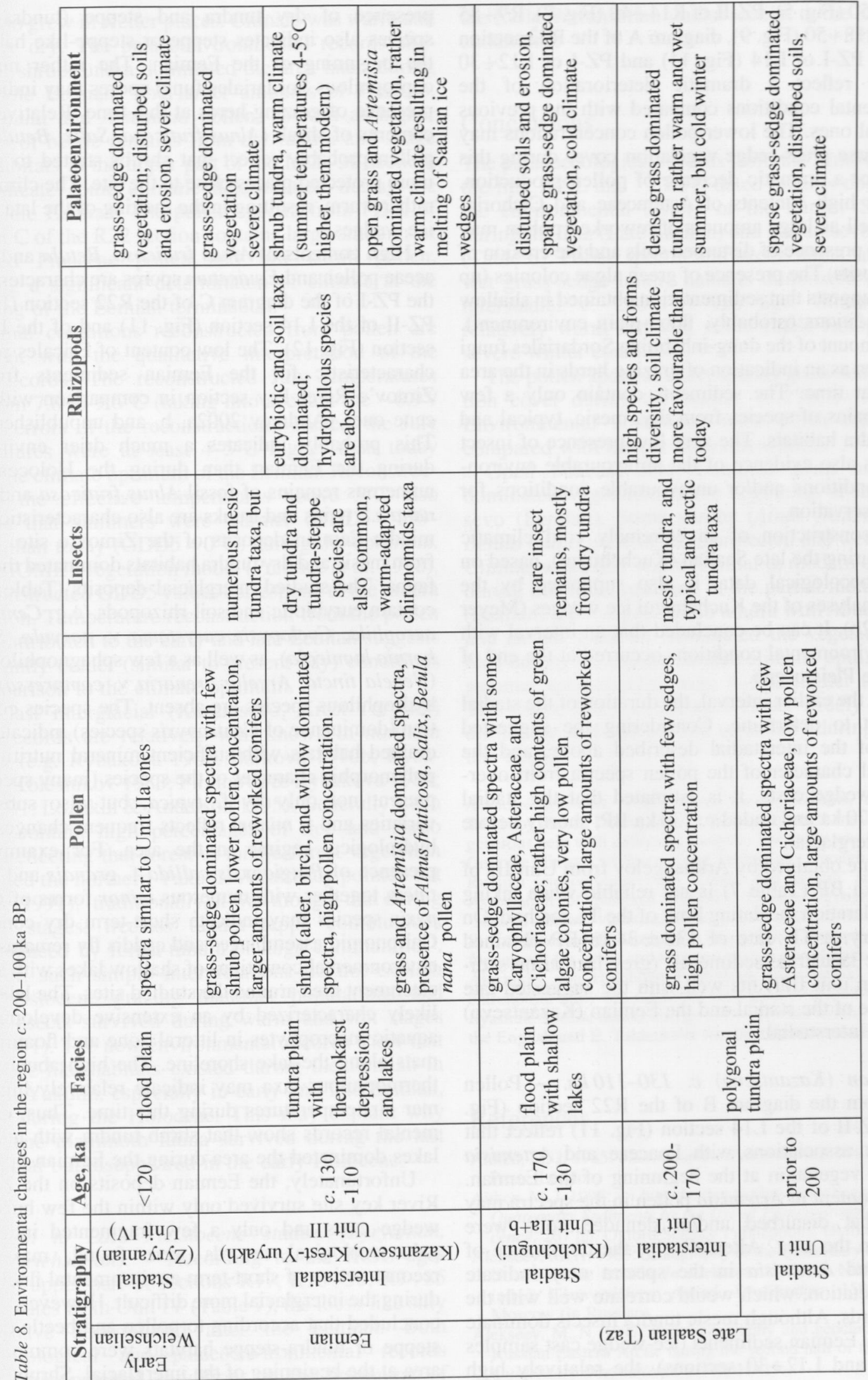


II of R8+50 (Fig. 5), PZ-II of R14+40 (Fig. 7), R9+85 (Fig. 8), R18+50 (Fig. 9), diagram A of the R22 section (Fig. 10), PZ-I of L14 (Fig. 11) and PZ-I of L12+30 (Fig. 12) reflect a dramatic deterioration of the environmental conditions compared with the previous interstadial ones. The lower pollen concentrations may reflect sparse grass-sedge vegetation cover during this time and/or a dramatic decrease of pollen production. Relatively high contents of Asteraceae and Cichoriaceae as well as large amounts of reworked pollen may mirror the presence of disturbed soils and the erosion of older deposits. The presence of green algae colonies (up to $15 \%$ ) suggests that sedimentation obtained in shallow water conditions (probably, flood-plain environment). A large amount of the dung-inhabiting Sordariales fungi can be seen as an indication of grazing herds in the area during that time. The sediments contain only a few insect remains of species from dry, mesic, typical and arctic tundra habitats. The very low presence of insect remains is also evidence of the unfavourable environmental conditions and/or unfavourable conditions for insect preservation.

The reconstruction of an extremely cold climatic interval during the late Saalian (Kuchchugui), based on the palaeoecological data, is also supported by the isotopic analyses of the Kuchchugui ice wedges (Meyer et al. 2002b). It can be concluded that an interval with severe environmental conditions occurred at the end of the Middle Pleistocene.

As with the earlier interval, the duration of the stadial is difficult to determine. Considering the suggested duration of the interstadial described above, and the interglacial character of the pollen spectra from overlying ice-wedge casts, it is estimated that the stadial began $c .170 \mathrm{ka}$ and ended $c .130 \mathrm{ka} \mathrm{BP}$, shortly before the last interglacial.

A TL date obtained by Arkhangelov from Unit IIa of $360 \pm 90 \mathrm{ka}$ BP (Table 7) is not reliable when taking into consideration the dating limit of the TL method. On the contrary, a TL date of $136 \pm 34 \mathrm{ka} \mathrm{BP}$ obtained from 'blue lacustrine sediments' (grey lacustrine sediments from unit III?) fits well with the suggested late Saalian age of the stadial and the Eemian (Kazantsevo) age of the interstadial.

The Eemian (Kazantsevo) c. 130-110 ka. - Pollen spectra from the diagram B of the R22 section (Fig. 10) and PZ-II of the L14 section (Fig. 11) reflect that open plant associations with Poaceae and Artemisia dominated vegetation at the beginning of the Eemian. The high content of Artemisia pollen in the spectra may indicate that disturbed and/or denuded soils were common in the area. Alternatively, the dominance of Poaceae and Artemisia in the spectra may indicate steppe vegetation, which would correlate well with the insect records. Although mesic tundra insects dominate in the early Eemian sediments (ice-wedge cast samples from $\mathrm{R} 22$ and $\mathrm{L} 12+30$ sections), the relatively high presence of dry tundra and steppe (tundra-steppe) species also indicates steppe or steppe-like habitats at the beginning of the Eemian. The rather numerous coprophilous Sordariales fungi spores may indicate the presence of grazing herds at this time. Relatively high contents of shrub (Alnus fruticosa, Salix, Betula nana) pollen probably reflect that shrubs started to grow in more protected places close to the site. The climate was rather warm, resulting in the melting of the late Saalian ice wedges.

High contents of Alnus fruticosa, Betula and Cyperaceae pollen and Equisetum spores are characteristic for the PZ-I of the diagram C of the R22 section (Fig. 10), PZ-II of the L14 section (Fig. 11) and of the L12+30 section (Fig. 12). The low content of Ericales pollen is characteristic for the Eemian sediments from the Zimov'e River key section in comparison with Holocene ones (Andreev 2002a, b, and unpublished data). This probably indicates a much drier environment during the Eemian than during the Holocene. The numerous remains of fossil Alnus fruticosa and Betula nana s.l. twigs and trunks are also characteristic for the middle Eemian deposits of the Zimov'e site. Species from mesic and dry tundra habitats dominated the beetle fauna. The studied interglacial deposits (Table 5) also contain eurybiotic and soil rhizopods (e.g. Centropyxis aerophila, Cyclopyxis eurystoma v. parvula, Schoenbornia humicola), as well as a few sphagnophilous ones (Nebela tincta, Arcella arenaria v. compressa), while hydrophilous species are absent. The species composition (dominance of Centropyxis species) indicates welldrained habitats with sufficient mineral nutrition. The polymorphic character of the species (many species are present not only by f. typica, but also subspecies, varieties and f. minor) reflects frequent changes of the hydrological regime in the area. For example, the presence of Plagiopyxis callida f. grandis and Nebela tincta together with numerous minor forms of Centropyxis species may indicate short-term dry conditions. Chironomid assemblages and caddis fly remains reflect environmental conditions of shallow lakes with a boggy catchment area around the studied sites. The lakes were likely characterized by an extensive development of aquatic macrophytes in littoral zone and floating moss mats along the lake shoreline. The high abundance of thermophilous taxa may indicate relatively high summer air temperatures during this time. Thus, environmental records show that shrub tundra with numerous lakes dominated the area during the Eemian optimum.

Unfortunately, the Eemian deposits on the Zimov'e River key site survived only within the few buried icewedge casts and only a few fragmented interglacial palaeoecological records were found, making the reconstruction of short-term environmental fluctuations during the interglacial more difficult. However, it can be concluded that according to pollen and beetle data, the steppe or tundra-steppe habitats were common in the area at the beginning of the interglacial. Shrub commu- 
nities also grew in wetter places. Climate was warm and relatively dry. The palaeoenvironmental records suggest that shrub tundra dominated the area later, during the middle Eemian. The larger amounts of Poaceae, Betula nana and Artemisia pollen, as well as higher numbers of beetle remains from dry tundra and sedge heath habitats in the upper part of the L12+30 section, may indicate some climatic deterioration during the middle-late Eemian. The pollen spectra from PZ-II of diagram $\mathrm{C}$ of the R22 section contains large amounts of reworked Pinaceae pollen and few shrub pollen, reflecting a significant deterioration of climate at the beginning of the Eemian termination.

Thermal conditions reconstructed from pollen are consistent with the qualitative interpretation of the proxy records. The reconstructed July temperatures vary from 7.8 to $9.6^{\circ} \mathrm{C}$ (taking into account the $-0.9^{\circ}$ / $+1.3^{\circ} \mathrm{C}$ errors of the reconstruction). Hence, the July temperatures were at least $4-5^{\circ} \mathrm{C}$ higher than today during the climate optimum of the Eemian. Reconstruction of the effective temperatures above $5^{\circ} \mathrm{C}$ also suggests that summers were warmer $(\mathrm{GDD} 5=150$ $230^{\circ} \mathrm{C}$ ) than today $\left(\mathrm{GDD} 5=0^{\circ} \mathrm{C}\right)$ during the optimum. In the BIOME1 vegetation model (Prentice et al. 1992), the reconstructed GDD5 values correspond to the tundra vegetation. Temperature reconstruction from the pollen spectra attributed to the early and late Eemian suggests significantly colder (similar to present day) conditions in comparison to the climate optimum.

The last interglacial (Kazantsevo, Krest-Yuryakh) pollen records are relatively well known in northern Yakutia (e.g. Rybakova 1962; Barkova 1970b; Rybakova \& Kolesnikov 1983; Pirumova \& Rybakova 1984; Sher 1991; Lozhkin \& Anderson 1995). Generally, such records contain high percentages of tree and shrub pollen, reflecting that forest or tundra-forest vegetation dominated the northern Yakutia. As already pointed out by Sher (1991), "traditionally, it was thought that during "warm" stages, treeless tundra-steppe communities were replaced by forest-tundra or taiga communities'. However, such simple interpretations do not explain how Pleistocene grazing mammal populations and steppe insects survived during warm and wet stages (Sher 1991). The new environmental records show that dry steppe-like habitats existed during the Eemian in northern Yakutia, especially in early and late Eemian, but not during the Holocene. This may explain why Pleistocene mammoth fauna survived during the last interglacial but disappeared in the early Holocene.

Transition to Late Pleistocene stadial (Zyryanian, Early Weichselian). - According to the IRSL ages from the upper part of sections R17, R18+50, R9+85 and TL dates from Unit IV (Table 7), the loess-like silty sands have accumulated after the Eemian. Both sedimentological and palaeoenvironmental records reflect environmental conditions at the beginning of the Early Weichselian stadial similar to the late Saalian conditions.

\section{Conclusions}

The palaeoecological records from the Zimov'e site are the first IRSL and ${ }^{230} \mathrm{Th} / \mathrm{U}$ dated records documenting the environmental history of the Laptev Sea region during the Taz (Late Saalian) and Kazantsevo (Eemian) (Table 8). Pollen spectra and beetle fauna suggest that wet grass-sedge tundra habitats dominated during the interstadial c. 200-170(?) ka ago. Summers were relatively warm and wet, while stable isotopes reflect severe winter conditions.

The pollen spectra reflect sparser grass-sedge vegetation cover during the stadial, c. 170(?)-130 ka ago. Environmental conditions were much more severe compared with the previous interstadial.

Open Poaceae and Artemisia plant associations dominated vegetation at the beginning of the Kazantsevo (Eemian). Some shrubs (Alnus fruticosa, Salix, Betula nana) grew in more protected and wetter places. Climate was fairly warm (similar to modern conditions) during this time, resulting in the partial melting of Taz (Saalian) ice wedges. Shrub tundra with Alnus fruticosa and Betula nana s.l. dominated the vegetation in the area during the middle Eemian climatic optimum, when summer temperatures were $4-5^{\circ} \mathrm{C}$ higher than today. The steppe-like habitats were rather widely distributed during the last interglacial, especially during early and late stages.

Acknowledgements. - We thank the participants, especially V. Tumskoy and A. Derevyagin, of the expedition 'Lena 1999' for their generous help with collecting samples. The study was funded by the German Ministry of Science and Technology through the GermanRussian science cooperation 'Laptev Sea System' and Helmholtz Association of National Research Centres through the project 'Natural climate variations from 10,000 years to the present day'. S. Kuzmina and T. Kuznetsova thank RFBR (project 01-04-48930) for support for insect and mammal studies. Pavel Tarasov thanks the Alexander von Humboldt Foundation for financial support. The chironomid study was supported via a grant awarded by DAAD to B. Ilyashuk. Special thanks also go to Drs. Kevin Fleming for reviewing the English and E. Taldenkova for identification of molluscs.

\section{References}

Aitken, M. J. 1985: Thermoluminescence Dating. 359 pp. Academic Press, London.

Aitken, M. J. 1998: An Introduction to Optical Dating - the Dating of Quaternary Sediments by the Use of Photon-Stimulated Luminescence. 267 pp. Oxford Science Publications, Oxford.

Alekseev, M. N. 1989: Stratigraphy of the Quaternary deposits of the Novosibirskie Islands. In Alekseev, M. N. \& Nikiforova, K. V. (eds.): Chetvertichnyy period. Stratigrafiya, 159-167. Nauka, Moscow (in Russian).

Alekseev, M. N. 1997: Palaeogeography and geochronology in the Russian Eastern Arctic during the second half of the Quaternary. Quaternary International 41/42, 11-15. 
Anderson, P. M. \& Lozhkin, A. V. 2001: The Stage 3 interstadial complex (Karginskii/middle Wisconsinan interval) of Beringia: variations in paleoenvironments and implications for paleoclimatic interpretations. Quaternary Science Reviews 20, 93-125.

Andreev, A. A., Peteet, D. M., Tarasov, P. E., Romanenko, F. A., Filimonova, L. V. \& Sulerzhitsky, L. D. 2001: Late Pleistocene Interstadial Environment on Faddeyevskiy Island, East-Siberian Sea, Russia. Arctic, Antarctic and Alpine Research 30, 28-35.

Andreev, A. A., Schirrmeister, L., Siegert, C., Bobrov, A. A., Demske, D., Seiffert, M. \& Hubberten, H.-W. 2002a: Paleoenvironmental changes in northeastern Siberia during the Upper Quaternary - evidence from pollen records of the Bykovsky Peninsula. Polarforschung 70, 13-25.

Andreev, A. A., Siegert, C., Klimanov, V. A., Derevyagin, A. Yu., Shilova, G. N. \& Melles, M. 2002b: Late Pleistocene and Holocene vegetation and climate changes in the Taymyr lowland, Northern Siberia reconstructed from pollen records. Quaternary Research 57, 138-150.

Andreev, A., Tarasov, P., Klimanov, V. \& Hubberten, H.-W. 2003a: Russian Arctic lakes as climatic archives: pollen-based reconstructions of the Late Quaternary climate. Terra Nostra 6, 17-21.

Andreev, A. A., Tarasov, P. E., Siegert, C., Ebel, T., Klimanov, V. A., Melles, M., Bobrov, A. A., Dereviagin, A. Y., Lubinski, D. \& Hubberten, H.-W. 2003b: Vegetation and climate changes on the northern Taymyr, Russia during the Upper Pleistocene and Holocene reconstructed from pollen records. Boreas 32, 484-505.

Andreev, A., Tarasov, P., Schwamborn, G., Ilyashuk, B., Ilyashuk, E., Bobrov, A., Klimanov, V., Rachold, V. \& Hubberten, H.-W. 2004: Holocene paleoenvironmental records from Nikolay Lake, Lena River Delta, Arctic Russia. Palaeogeography, Palaeoclimatology, Palaeoecology 209, 197-217.

Arkhangelov, A. A., Mikhalev, D. V. \& Nikolaev, V. I. 1996: About early epochs of permafrost formation in northern Yakutia and age of ancient relicts of underground glaciation. In Velichko, A. A., Arkhangelov, A. A., Borisova, O. K., Gribchenko, Yu. N., Drenova, A. N., Zelikson, E. M., Kurenkova, E. N., Mikhalev, D. V., Nikolaev, V. I., Novenko, E. Yu. \& Timireva, S. A. (eds.): Razvitie oblasti mnnogoletnei merzloty i periglyatsial'noi zony Severnoi Evrazii $i$ usloviya rasseleniya drevnego cheloveka, 102109. Institute of Geography, Moscow (in Russian).

Atlas \& Arktiki 1985: GUGK, Moscow (in Russian).

Balik, V. 1994: On the soil testate amoebae fauna (Protozoa: Rhizopoda) on the Spitsbergen Islands (Svalbard). Archiv für Protistenkunde 144, 365-372.

Barkova, M. B. 1970a: Spore-pollen complexes of Middle Pleistocene sediments of Yana-Indigirka Rivers lowland. Uchenye zapiski NIIGA 30, 40-46 (in Russian).

Barkova, M. B. 1970b: Spore-pollen complexes of pre-glacial and first glacial epochs of Late Pleistocene sediments of YanaIndigirka Rivers lowland. Uchenye zapiski NIIGA 31, 40-46 (in Russian).

Barkova, M. B. 1982: Palynological data for the Middle Pleistocene stratigraphy of coastal zones of Laptev and East-Siberian Seas. In Shulgina, N. I. (ed.): Stratigrafiya i paleogeografiya pozdnego kaynozoya Arktiki, 90-96. PGO 'Sevmorgeologiya' Ministry of Geology, Leningrad (in Russian).

Barkova, M. B. 1990: Spore-pollen complexes of the Middle Pleistocene of Yana-Kolyma region and their significance for stratigraphy and correlation of sediments. In Shulgina, N. I. (ed.): Stratigrafiya i paleontologiya mezo-kaynozoya Sovetskoi Arktiki, 113-127. PGO 'Sevmorgeologiya' Ministry of Geology, Leningrad (in Russian).

Berglund, B. E. \& Ralska-Jasiewiczowa, M. 1986: Pollen analysis and pollen diagrams. In Berglund, B. (ed.): Handbook of Holocene Palaeoecology and Palaeohydrology, 455-484. Interscience, New York.

Beyens, L., Chardez, D. \& Van de Vijver, B. 2000: A contribution to the protist-diversity in the polar regions: testate amoebae date from the Russian Arctic. In Ceulemans, R., Bogaert, J., Deckmyn,
G. \& Nijs, I. (eds.): Topics in Ecology. Structure and Function in Plants and Ecosystems, 101-110. Wilrijk, Antwerpen.

Bobrov, A. A., Siegert, C., Andreev, A. A. \& Schirrmeister, L. 2004: Testate amoebae (Rhizopoda: Testacealobosea and Testaceafilosea) as bioindicators in the Late Quaternary deposits of the Bykovsky Peninsula, Laptev Sea, Russia. Palaeogeography, Palaeoclimatology, Palaeoecology 209, 165-181.

Bunge, A. A. 1887: Bericht über den ferneren Gang der Expedition. Reise nach den Neusibirischen Inseln. Aufenthalt auf der Grossen Ljachof-Insel. In Schrenk, L. V. \& Maximovicz, C. J. (eds.): Expedition zu den Neusibirischen Inseln und dem Jana-Lande (1885), Beitraege zur Kenntnis des russischen Reiches und der angrenzenden Laender, Vol. III, 231-284.

Chardez, D. 1965: Ecologie generale des Thecamoebiens (Rhizopoda, Testacea). Bulletin de l'Institut Agronomigue et des Stations de Recherches Gembloux 2, 306-341.

Chardez, D. 1967: Monographie du genre Quadrulella Cockerell (Protozoa, Rhizopoda testacea). Bulletin de l'Institut Agronomigue et des Stations de Recherches Gembloux 3, 229-241.

Duller, G. 2001: Luminescence Analyst - Software Version 3.05b. University of Wales, Aberystwyth.

Gavrilov, A. V. \& Tumskoy, V. E. 2001: Evolution of mean annual ground temperature on coastal lowlands of Yakutia in Middle and Late Pleistocene. Kriosfera Zemli 3, 3-16 (in Russian).

Giterman, R. E. 1976: Vegetation of the young periods of the Pleistocene in Kolyma lowland with connection of Polar Beringia. In Kontrimavichus, V. L. (ed.): Beringiya v kaynozoe. Materialy vsesoyuznogo simpoziuma 'Beringiyskaya susha $i$ ee znachenie dlya razvitiya goloarkticheskikh flor i faun v kaynozoe', 166-168. DVNTs AN SSSR, Vladivostok (in Russian).

Giterman, R. E. 1977: Palynological characteristics of the Karga interglacial complex of North-East of USSR and its analogues in Northern America. In Lozhkin, A. V. (ed.): Palynologicheskoe obosnovanie stratigrafii antropogena, 40-60. Nauka, Moscow (in Russian).

Grigoriev, M. N., Imaev, V. S., Koz'min, B. M., Kunitski, V. V., Larionov, A. G., Mikulenko, K. I., Skryabin, R. M. \& Timirshin, K. V. 1996: Geologiya, seismichnost' $i$ kriogennye protsessy $v$ arcticheskikh raionakh zapadnoi Yakutii. 80. Scientific Center SD RAS, Yakutsk (in Russian).

Grimm, E. 1991: TILIA and TILIAGRAPH. Illinois State Museum, Springfield, Illinois.

Grosse, G. 2001: Geochronologie mit Infrarot Optisch Stimulierter Lumineszenz an spätquartären Sedimenten der Laptevsee-Küste, nordsibirische Arktis. M.Sc. thesis, Technical University Freiberg, $97 \mathrm{pp}$.

Grosse, G., Krbetschek, M. \& Schirrmeister, L. In press: Luminescence dating (IRSL) of sediments from permafrost sequences of NE-Siberia (Bykovsky Peninsula). Quaternary Research.

Guiot, J. 1990: Methodology of palaeoclimatic reconstruction from pollen in France. Palaeogeography, Palaeoclimatology, Palaeoecology 80, 49-69.

Grün, R. 1992: Age - application software. Risø National Institute, Risø.

Huett, G. \& Jaeck, I. 1989: The validity of the laboratory reconstruction of paleodose. Ancient TL 7, 48-50.

Igarashi, Y., Fukuda, M., Nagaoka, D. \& Saljo, K. 1995: Vegetation and climate during accumulating period of yedoma, inferred from pollen records. In Takahashi, K., Osawa, A. \& Kanazawa, Y. (eds.): Proceedings of the Third Symposium on the Joint Siberian Permafrost Studies between Japan and Russia in 1994, 139-146. Hokkaido University, Tsukuba.

Isaeva, L. L. 1984: Late Pleistocene glaciation of north central Siberia. In Velichko, A. A., Wright, H. \& Barnosky, K. (eds.): Late Quaternary Environments of the Soviet Union, 21-30. University of Minnesota Press, Minneapolis.

Kaplan, J. O. 2001: Geophysical Applications of Vegetation Modeling. Ph.D. dissertation, Lund University. 113 pp.

Kaplina, T. N. 1979: Spore-pollen spectra of deposits of 'the Ice 
Complex' in the coastal lowlands of Yakutia. Izvestiya Akademii Nauk SSSR. Seriya geograficheskaya 2, 85-93 (in Russian).

Kaplina, T. N. \& Giterman, R. E. 1983: Molotkovskiy Kamen' - a key section of the second half of the Late Pleistocene in the Kolyma Lowland. Izvestiya Akademii Nauk. Seriya geologicheskaya 6, 79-83 (in Russian).

Kaplina, T. N., Giterman, R. E., Lakhtina, O. V., Abrashov, B. A., Kiselyov, S. V. \& Sher, A. V. 1978: Duvannyy Yar - a key section of Upper Pleistocene deposits of the Kolyma lowland. Byulleten' komissii po izucheniyu chetvertichnogo perioda 48, 49-65 (in Russian).

Kaplina, T. N., Sher, A. V., Giterman, R. E., Zazhigin, V. S., Kiselyov, S. V., Lozhkin, A. V. \& Nikitin, V. P. 1980: Key section of Pleistocene deposits on the Allaikha River (lower reaches of the Indigirka). Byulleten' komissii po izucheniyu chetvertichnogo perioda 50, 73-95 (in Russian).

Kienast, F. 2002: Die Rekonstruktion der spätquartären Vegetationsund Klimageschichte der Laptewsee-Region auf der Basis botanischer Großrestuntersuchungen. Ph.D. dissertation, Potsdam University, $122 \mathrm{pp}$.

Krbetschek, M., Götze, J., Dietrich, A. \& Trautmann, T. 1997: Spectral information from minerals relevant for luminescence dating. Radiation Measurements 27, 695-748.

Krbetschek, M., Gonser, G. \& Schwamborn, G. 2002: Luminescence dating results of sediment sequences of Lena Delta. Polarforschung 70, 83-88.

Kunitsky, V. V. 1996: Chemical composition of ice wedges of the Ice Complex. In Klimovski, I. V., Shepelev, V. A. \& Lyubomirov, A. S. (eds.): Kriolitozona $i$ gruntovye vody v Sibiri: Morfologiya kriolitozony, 93-117. Permafrost Institute, Yakutsk (in Russian).

Kunitsky, V. V. 1998: The Ice Complex and cryoplanation terraces of Bol'shoy Lyakhovsky Island. In Kamensky, R. M., Kunitsky, V. V., Olovin, B. A. \& Shepelev, V. V (eds.): Problemy geokriologii, 60-72. Permafrost Institute, Yakutsk (in Russian).

Kunitsky, V. V., Schirrmeister, L., Grosse, G., Kuznetsova, T., Kuzmina, S. \& Tumskoy, V. 2000: Quaternary deposits of the Bol'shoy Lyakhovsky Island. Reports on Polar and Marine Research 354, 113-164.

Kuzmina, S. A. 2002: Quaternary Insects of Yakutian Coastal Lowlands. Ph.D. dissertation, Paleontological Institute, Moscow, $420 \mathrm{pp}$.

Lozhkin, A. V. 1977: Radiocarbon dates of the Upper Pleistocene deposits on Novosibirskie Islands and the age of the yedoma complex of the north-eastern USSR. Doklady Akademii Nauk SSSR 235, 435-437 (in Russian).

Lozhkin, A. V. 1987: Geochronology of Late Anthropogene of the north-eastern USSR. In Punning, J.-M. K., Ivanova, I. K., Kind, N. V. \& Chichagova, O. A. (eds.): Novye dannye po geokhronologii chetvertichnogo perioda, 172-179. Nauka, Moscow (in Russian).

Lozhkin, A. V. \& Anderson, P. M. 1995: The Last Interglacial in Northeast Siberia. Quaternary Research 43, 147-158.

Makarchenko, E. A. \& Makarchenko, M. A. 1999: Chironomidae. Non-biting midges. In Tsalolikhin, S. J. (ed.): Key to Freshwater Invertebrates of Russia and Adjacent Lands. V.4; Higher Insects. Diptera, 210-295 and 670-857. Zoological Institute, St. Petersburg (in Russian).

Makeyev, V. M., Arslanov, Kh. A., Baranovskaya, O. F., Kosmodamianskiy, A. V., Ponomareva, D. P. \& Tertychnaya, T. V. 1989: Stratigraphy, geochronology and paleogeography of Late Pleistocene and Holocene of Kotel'nyy Island. Byulleten' komissii po izucheniyu chetvertichnogo perioda 58, 58-69 (in Russian).

Makeyev, V. M., Ponomareva, D. P., Pitulko, V. V., Chernova, G. M. \& Solovyeva, D. V. 2003: Vegetation and climate of New Siberian Islands for the past 15,000 years. Arctic, Antarctic and Alpine Research 35, 28-35.

Mejdahl, V. 1988: Long-term stability of the TL signal in alkali feldspars. Quaternary Science Reviews 7, 357-360.

Meyer, H., Siegert, C., Derevyagin, A. \& Hubberten, H.-W. 2002a: Paleoclimatic changes in the Late Quaternary - evidences from stable isotopes of ground ice of the Bykovsky Peninsula, NE Siberia. Polarforschung 70, 37-53.

Meyer, H., Siegert, C., Derevyagin, A., Schirrmeister, L. \& Hubberten, H.-W. 2002b: Paleoclimate reconstruction on Big Lyakhovsky Island, North Siberia - hydrogen and oxygen isotopes in ice wedges. Permafrost and Periglacial Processes 13, 91-103.

Nagaoka, D. 1994: Properties of Ice Complex deposits in eastern Siberia. In Inoue, G. (ed.): Proceedings of the Second Symposium on the Joint Siberian Permafrost Studies between Japan and Russia in 1993, 14-18. Hokkaido University, Isebu.

Nagaoka, D., Saljo, K. \& Fukuda, M. 1995: Sedimental environment of the Yedoma in high Arctic eastern Siberia. In Takahashi, K., Osawa, A. \& Kanazawa, Y. (eds.): Proceedings of the Third Symposium on the Joint Siberian Permafrost Studies between Japan and Russia in 1994, 8-13. Hokkaido University, Tsukuba.

Nowaczyk, N. R. \& Antonow, M. 1997: High-resolution magnetostratigraphy of four sediment cores from the Greenland Sea. I. Identification of the Mono Lake excursion, Laschamp and Biwa I/ Jamaica geomagnetic polarity events. Geophysic Journal International 131, 310-324.

Ogden, C. G. \& Hedley, R. H. 1980: An Atlas of Freshwater Testate Amoebae. 222 pp. Oxford University Press, Oxford.

Pirumova, L. G. \& Rybakova, N. O. 1984: The main stages of the Late Cenozoic sedimentation in Northern Yakutia (according to data of spore-pollen and diatom analyses). In Korotkiy, A. N. (ed.): Paleogeograficheskie rubezhi i metody ikh izucheniya, $63-$ 81. DVNTs, Vladivostok (in Russian).

Prentice, I. C., Cramer, W., Harrison, S. P., Leemans, R., Monserud, R. A. \& Solomon, A. M. 1992: A global biome model based on plant physiology and dominance, soil properties and climate. Journal of Biogeography 19, 117-134.

Romanovskii, N. N. 1958a: New data about Quaternary deposits structure on the Bol'shoy Lyakhovsky Island (Novosibirskie Islands). Nauchnye doklady vysshei shkoly. Seriya geologogeograficheskaya 2, 243-248 (in Russian).

Romanovskii, N. N. 1958b: Paleogeographical conditions of formation of the Quaternary deposits on Bol'shoy Lyakhovsky Island (Novosibirskie Islands). In Bogorov, V. G. (ed.): Voprosy fizicheskoi geografii polyarnykh stran. Vypysk I, 80-88. Moscow State University, Moscow (in Russian).

Romanovskii, N. N. 1958c: Permafrost structures in Quaternary deposits. Nauchnye doklady vysshei shkoly. Seriya geologogeograficheskaya 3, 185-189 (in Russian).

Rybakova, N. O. 1962: Micropaleobotanical characteristics of Quaternary deposits in Arctic Yakutia. Vestnik Moskovskogo Universiteta 6, 55-63 (in Russian).

Rybakova, N. O. \& Kolesnikov, S. F. 1983: New evidence on the Upper Cenozoic deposits in the coastal lowlands of Yakutia. Byulleten' Moskovskogo obshestva ispytateley prirody. Otdelenie geologii 60, 83-88 (in Russian).

Rybakova, N. O. \& Pirumova, L. G. 1986: Conditions of accumulation and stratification of the Upper Pleistocene and Holocene deposits in Northern Yakutia (by data of spore-pollen and diatom analyses). Byulleten' Moskovskogo obshestva ispytateley prirody. Otdelenie geologii 61, 118-119 (in Russian).

Schirrmeister, L., Kunitsky, V. V., Grosse, G., Schwamborn, G., Andreev, A. A., Meyer, H., Kuznetsova, T. V., Bobrov, A. A. \& Oezen, D. In press: Late Quaternary history of the accumulation plain north of the Chekanovsky Ridge (north-eastern Yakutia). Polar Geography.

Schirrmeister, L., Oezen, D. \& Geyh, M. A. 2002b: ${ }^{230} \mathrm{Th} / \mathrm{U}$ dating of frozen peat, Bol'shoy Lyakhovsky Island (North Siberia). Quaternary Research 57, 253-258.

Schirrmeister, L., Siegert, C., Kuznetsova, T., Kuzmina, S., Andreev, A. A., Kienast, F., Meyer, H. \& Bobrov, A. A. 2002a: Paleoenvironmental and paleoclimatic records from permafrost deposits in the Arctic region of Northern Siberia. Quaternary International 89, 97-118.

Schwamborn, G., Rachold, V. \& Grigoriev, M. N. 2002: Late 
Quaternary sedimentation history of the Lena Delta. Quaternary International 89, 119-134.

Sher, A. V. 1991: Problems of the Last Interglacial in Arctic Siberia. Quaternary International 10-12, 215-222.

Sher, A. V., Giterman, R. E., Zazhigin, V. S. \& Kiselyov, S. V. 1977: New data on the Late Cenozoic deposits of the Kolyma Lowland. Izvestiya Akademii Nauk SSSR. Seriya geologicheskaya 5, 67-83 (in Russian).

Sher, A., Kuzmina, S. \& Kuznetsova, T. 2002: Pleistocene climate drivers of the east Siberian shelf land. Terra Nostra 3, 101-102.

Shingvi, A. K., Bronger, A., Sauer, W. \& Pant, R. K. 1989 Thermoluminescence dating of Loess-Palaeosoil sequences in the Carpathian basin (East-Central Europe): a suggestion for a revised chronology. Chemical Geology 73, 307-317.

von Toll, E. V. 1897: Fossil glaciers of New Siberian Islands and their relation to mammoth corpses and Glaciation Period. Zapiski
Imperatorskogo Russkogo Geograficheskogo obshestva po obshei geografii 32, 1-137 (in Russian).

Tomirdiaro, S. V. 1980: Loess-Ice Formation of East Siberia in the Late Pleistocene and Holocene. 184 pp. Nauka, Moscow (in Russian).

Walker, I. R. 2001: Midges: Chironomidae and related Diptera. In Smol, J. P., Birks, H. J. B. \& Last, W. M. (eds.): Tracking Environmental Change Using Lake Sediments. Vol. 4. Zoological Indicators, 43-66. Kluwer Academic Publishers, Dordrecht.

Wiederholm, T. 1983: Chironomidae of the Holarctic region, keys and diagnoses. Part 1 - Larvae. Entomologica Scandinavica (Suppl.) 19, 1-457.

Zöller, L., Stremme, H. \& Wagner, G. A. 1988: ThermolumineszenzDatierung an Löss-Paläoboden-Sequenzen von Nieder-, Mittelund Oberrhein/Bundesrepublik Deutschland. Chemical Geology $73,39-62$. 